\title{
Article
}

\section{Effect of zinc intake on growth in infants: A meta-analysis}

Nissensohn, M., Sánchez-Villegas, A., Fuentes Lugo, D., Henríquez Sánchez, P, Doreste Alonso, J, Peña Quintana, L, Ruano, C., Lowe, Nicola M, Hall Moran, Victoria Louise, Skinner, A.L., Warthonmedina, Marisol and Serra-Majem, L.

Available at http://clok.uclan.ac.uk/11559/

Nissensohn, M., Sánchez-Villegas, A., Fuentes Lugo, D., Henríquez Sánchez, P, Doreste Alonso, J, Peña Quintana, L, Ruano, C., Lowe, Nicola M ORCID: 00000002-6934-2768, Hall Moran, Victoria Louise ORCID: 0000-0003-3165-4448 et al (2014) Effect of zinc intake on growth in infants: A meta-analysis. Critical Reviews in Food Science and Nutrition, 56 (3). pp. 350-363. ISSN 1040-8398

It is advisable to refer to the publisher's version if you intend to cite from the work. http://dx.doi.org/10.1080/10408398.2013.802661

For more information about UCLan's research in this area go to http://www.uclan.ac.uk/researchgroups/ and search for <name of research Group>.

For information about Research generally at UCLan please go to http://www.uclan.ac.uk/research/

All outputs in CLoK are protected by Intellectual Property Rights law, including Copyright law. Copyright, IPR and Moral Rights for the works on this site are retained by the individual authors and/or other copyright owners. Terms and conditions for use of this material are defined in the policies page.

\section{CLoK}

Central Lancashire online Knowledge www.clok.uclan.ac.uk

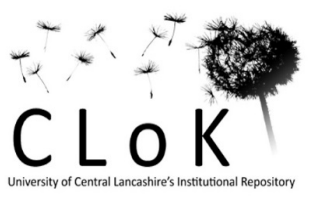


This article was downloaded by: [University of Central Lancashire]

On: 04 March 2015, At: 02:28

Publisher: Taylor \& Francis

Informa Ltd Registered in England and Wales Registered Number: 1072954 Registered office: Mortimer House, 37-41 Mortimer Street, London W1T 3J H, UK

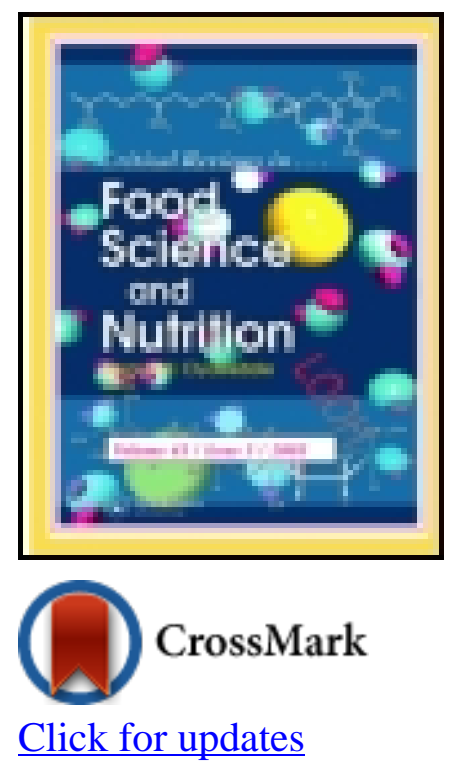

\title{
Critical Reviews in Food Science and Nutrition
}

Publication details, including instructions for authors and subscription information: http:// www.tandfonline.com/loi/bfsn20

\section{Effect of zinc intake on growth in infants: A meta- analysis}
M. Nissensohn ${ }^{\mathrm{ab}}$, A. Sánchez-Villegas ${ }^{\mathrm{ab}}$, D. Fuentes Lugo ${ }^{\mathrm{c}}, \mathrm{P}$ Henríquez Sánchez ${ }^{\mathrm{ab}}$, J Doreste Alonso $^{\text {ab }}$, L Peña Quintana ${ }^{\text {ad }}$, C. Ruano ${ }^{\text {ab }}$, N. L. Lowe ${ }^{e}$, V. Hall Moran ${ }^{f}$, A. L. Skinner ${ }^{e}$, M. Warthon-Medina ${ }^{\mathrm{e}} \&$ L. Serra-Majem ${ }^{\text {ab }}$
a Department of Clinical Sciences, University of Las Palmas de Gran Canaria, Las Palmas de Gran Canaria, Spain
${ }^{\text {b }}$ Ciber Fisiopatología Obesidad y Nutrición (CIBEROBN, CB06/03), Instituto de Salud Carlos III, Madrid, Spain
${ }^{c}$ Faculty of Health Sciences, Unacar, Ciudad del Carmen, México
${ }^{d}$ Unit of Gastroenterology, Hepatology and Pediatric Nutrition. Complejo Hospitalario Universitario Insular Materno-Infantil de Las Palmas. Las Palmas de Gran Canaria, Spain
${ }^{\mathrm{e}}$ International Institute of Nutritional Sciences and Food Safety Studies, University of Central Lancashire, Preston, UK
${ }^{f}$ Maternal \& Infant Nutrition \& Nurture Unit, University of Central Lancashire, Preston, UK Accepted author version posted online: 03 Nov 2014.

\begin{abstract}
To cite this article: M. Nissensohn, A. Sánchez-Villegas, D. Fuentes Lugo, P Henríquez Sánchez, J Doreste Alonso, L Peña Quintana, C. Ruano, N. L. Lowe, V. Hall Moran, A. L. Skinner, M. Warthon-Medina \& L. Serra-Majem (2014): Effect of zinc intake on growth in infants: A meta-analysis, Critical Reviews in Food Science and Nutrition, DOI: 10.1080/ 10408398.2013.802661
\end{abstract}

To link to this article: http:// dx.doi.org/ 10.1080/ 10408398.2013.802661

Disclaimer: This is a version of an unedited manuscript that has been accepted for publication. As a service to authors and researchers we are providing this version of the accepted manuscript (AM). Copyediting, typesetting, and review of the resulting proof will be undertaken on this manuscript before final publication of the Version of Record (VoR). During production and pre-press, errors may be discovered which could affect the content, and all legal disclaimers that apply to the journal relate to this version also.

\section{PLEASE SCROLL DOWN FOR ARTICLE}

Taylor \& Francis makes every effort to ensure the accuracy of all the information (the "Content") contained in the publications on our platform. However, Taylor \& Francis, our agents, and our licensors make no representations or warranties whatsoever as to the accuracy, completeness, or suitability for any purpose of the Content. Any opinions and views expressed in this publication are the opinions and views of the authors, and are not the views of or endorsed by Taylor \& Francis. The accuracy of the Content should not be relied upon and should be independently verified with primary sources of information. Taylor and Francis shall not be liable for any losses, actions, claims, proceedings, demands, costs, expenses, damages, and other liabilities whatsoever or howsoever caused arising directly or indirectly in connection with, in relation to or arising out of the use of the Content.

This article may be used for research, teaching, and private study purposes. Any substantial or systematic reproduction, redistribution, reselling, loan, sub-licensing, systematic supply, or distribution in any 
form to anyone is expressly forbidden. Terms \& Conditions of access and use can be found at http:// www.tandfonline.com/page/terms-and-conditions 


\section{ACCEPTED MANUSCRIPT}

\section{Effect of zinc intake on growth in infants: A meta-analysis}

Nissensohn M. ${ }^{1-2 *}$; Sánchez-Villegas A. ${ }^{1-2}$; Fuentes Lugo D. ${ }^{3}$; Henríquez Sánchez P. ${ }^{1-2}$;

Doreste Alonso J. ${ }^{1-2}$; Peña Quintana L. ${ }^{1-4}$; Ruano C. ${ }^{1-2}$; Lowe N.L. ${ }^{5}$; Hall Moran V..$^{6}$;

Skinner A.L. ${ }^{5}$; Warthon-Medina M. ${ }^{5}$ and Serra-Majem L. ${ }^{1-2}$

${ }^{1}$ Department of Clinical Sciences, University of Las Palmas de Gran Canaria, Las Palmas de Gran Canaria, Spain,

${ }^{2}$ Ciber Fisiopatología Obesidad y Nutrición (CIBEROBN, CB06/03), Instituto de Salud Carlos

III, Madrid, Spain,

${ }^{3}$ Faculty of Health Sciences, Unacar, Ciudad del Carmen, México,

${ }^{4}$ Unit of Gastroenterology, Hepatology and Pediatric Nutrition. Complejo Hospitalario

Universitario Insular Materno-Infantil de Las Palmas. Las Palmas de Gran Canaria, Spain,

${ }^{5}$ International Institute of Nutritional Sciences and Food Safety Studies, University of Central

Lancashire, Preston, UK,

${ }^{6}$ Maternal \& Infant Nutrition \& Nurture Unit, University of Central Lancashire, Preston, UK.

*Corresponding Author:

Nissensohn Mariela, Department of Clinical Sciences, University of Las Palmas de Gran

Canaria, Las Palmas de Gran Canaria, Spain

Email: mnissensohn@acciones.ulpgc.es 


\section{ACCEPTED MANUSCRIPT}

\section{Abstract}

A systematic review and meta-analysis of available randomised controlled trials (RCTs) was conducted to evaluate the effect of zinc $(\mathrm{Zn})$ intake on growth in infants. Out of 5500 studies identified through electronic searches and reference lists, 19 RCTs were selected after applying the exclusion/inclusion criteria. The influence of $\mathrm{Zn}$ intake on growth was considered in the overall meta-analysis. Other variables were also taken into account as possible effect modifiers: doses of $\mathrm{Zn}$ intake, intervention duration, nutritional status and risk of bias. From each select growth study, final measures of Weight, Length, Mid upper arm circumference (MUAC), Head circumference, Weight for age z-score (WAZ), Length for age z-score (LAZ) and Weight for Length z-score (WLZ) were assessed. Pooled $\beta$ and 95\% confidence interval (CI) were calculated. Additionally we carried out a sensitivity analysis. $\mathrm{Zn}$ intake was not associated to Weight, Length, MUAC, Head Circumference and LAZ in the pooled analyses. However, Zn intake had a positive and statistically effect on WAZ $(\beta=0.06 ; 95 \% \mathrm{CI} 0.02$ to 0.10$)$ and WLZ ( $\beta$ $=0.05 ; 95 \% \mathrm{CI} 0.01$ to 0.08$)$. The dose response relationship between $\mathrm{Zn}$ intake and these parameters indicated that a doubling of $\mathrm{Zn}$ intake increased WAZ and WLZ by approximately 4\%. Substantial heterogeneity was present only in Length analyses. $\left(\mathrm{I}^{2}=45 \% ; \mathrm{p}=0.03\right) . \mathrm{Zn}$ intake was positively associated with length values at short time (4 to 20 weeks) $(\beta=0.01$; CI $95 \% 0$ to 0.02$)$ and at medium doses of $\mathrm{Zn}(4.1$ to $8 \mathrm{mg} /$ day) $(\beta=0.003$; CI $95 \% 0$ to 0.01$)$. Nevertheless, the effect magnitude was small. Our results indicate that $\mathrm{Zn}$ intake increases growth parameters of infants. Nonetheless, interpretation of these results should be carefully considered.

Keywords: EURRECA, zinc intake, growth, infants 


\section{ACCEPTED MANUSCRIPT}

\section{Introduction}

Zinc $(\mathrm{Zn})$ is an essential nutrient, present in all body tissues and fluids. The biologic role of $\mathrm{Zn}$ is now recognized in structure and function of proteins, including more than 300 enzymes, transcription factors, hormonal receptor sites, and biologic membranes. $\mathrm{Zn}$ has numerous central roles in DNA and RNA metabolism (MacDonald 2000), and it is involved in signal transduction, gene expression, and apoptosis. Zn enzymes are involved in nucleic acid metabolism, cellular proliferation, differentiation and growth (Chesters 1978). $\mathrm{Zn}$ is a critical micronutrient for normal growth, haematopoiesis, immune function and neurologic development during infancy. Infants have a relatively high requirement of $\mathrm{Zn}$ per unit body weight during a sensitive period of rapid growth and development (Hermoso et al. 2010).

Physiological functional consequences (e.g. growth retardation) of mild Zn deficiency are often apparent before the $\mathrm{Zn}$ concentrations in plasma and/or tissues are significantly reduced (Gibson et al. 1989; Ruz et al. 1991). Inadequate $\mathrm{Zn}$ intake is likely to be an important contributing factor of growth failure in children that are malnourished, because diets lows in protein tend to be low in $\mathrm{Zn}$ (Golden \& Golden 1981). Growth faltering starts at 6 mo of age in less-developed countries with rapid progression (The World Bank 2006) and coincides with a critical time in the dietary supply of Zn, labelled as a "problem" nutrient in complementary feeding by WHO. (Dewey \& Brown 2003)

Human Zn deficiency was described since the early 1960s. But it was not until 1990, when the $\mathrm{Zn}$ became to be a micronutrient of major interest until the current date, due the important function for immune system integrity (Shankar \& Prasad 1998), the know losses of $\mathrm{Zn}$ in 


\section{ACCEPTED MANUSCRIPT}

diarrheal fluids (Ruz \& Solomons 1990), and pilot data on the association between Zn deficiency and diarrhea (Hambidge 1992). Zn supplementation RCT's focused on growth velocity in young children. A comprehensive meta-analysis of results of 33 studies provided convincing evidence of a significant increase in linear growth (Brown et al. 1998; IZNCG 2004).

A considerable number of intervention trials have been completed in multiple countries to assess the effect of supplemental $\mathrm{Zn}$ on children's growth. However, these studies have yielded inconsistent results, possibly because of differences in 1) the pre-existing $\mathrm{Zn}$ status of the study subjects, 2) the content and bioavailability of $\mathrm{Zn}$ in the local diets, and 3) the incidence of common infections that can affect growth independently of an individual's Zn status. Moreover, methodology aspects of these studies, such as variations in the dose, the sample sizes, the method of administration or the duration of supplementation, may have influenced their results (Brown et al. 2002).

Recommendations for $\mathrm{Zn}$ intake during infancy vary widely across Europe, ranging from 1 $\mathrm{mg} /$ day up to $5 \mathrm{mg} /$ day (Hermoso et al. 2010). The EURRECA project attempts to consolidate the basis for the definition of micronutrient requirements across Europe, taking into account relationships among intake, status and health outcomes, in order to harmonise these recommendations (Ashwell et al. 2008). This paper presents a systematic review of the data from all available randomized controlled trials (RCTs) meeting EURRECA's quality standard (Matthys et al. 2011), which investigated $\mathrm{Zn}$ intake and growth parameters in infants, and combines these studies in meta-analyses to model of growth as a function of $\mathrm{Zn}$ intake. 


\section{ACCEPTED MANUSCRIPT}

\section{Materials and Methods}

\section{Search strategy}

This research was conducted within the framework of the European Micronutrient Recommendations Aligned (EURRECA) Network of Excellence that aims to identify the micronutrient requirements for optimal health in European populations (http://www.eurreca.org).

This review was part of a wider review process to identify studies assessing the effect of $\mathrm{Zn}$ intake

on different outcomes (health outcomes). The wider searches were performed for literature published up to and including February 2010. The databases MEDLINE, EMBASE and Cochrane

were accessed using search terms 'study designs in humans' and 'zinc' and 'intake'. Both indexing

and text terms were used and languages included were restricted to those spoken in the EURRECA

Network (English, Dutch, French, German, Hungarian, Italian, Norwegian, Polish, Spanish, Greek

and Serbian.). The Ovid MEDLINE search strategy can be found in Table 1. Reference lists of retrieved articles and published literature reviews were also checked for relevant studies. The 


\section{ACCEPTED MANUSCRIPT}

procedure for the identification, selection of articles and data extraction is illustrated in Fig. 1.

\section{Selection of articles}

Titles of articles identified from the searches were entered into an EndNote library. Papers were considered eligible for inclusion if they were RCTs, conducted in human infants (aged 0-12 months), and studied the effect of supplements, fortified foods or micronutrient intake from natural food sources, and assessed Zn concentrations in serum/plasma. Zn intake was assessed from breast milk, infant formula and food sources (e.g. fortified formula or cereal) and supplements.

Exclusion criteria applied were: studies conducted in animals; combined interventions e.g. >1 micronutrient or micronutrient + lifestyle intervention which did not study the effect of the micronutrient separately; non primary studies (e.g. letters and narrative literature reviews); duplicate publications; studies where the $\mathrm{Zn}$ intake - growth relationship was not reported or health outcomes other than growth assessed.

Briefly, titles and abstracts of the $10 \%$ of the library were screened in duplicate for eligibility by two reviewers and any discrepancies were discussed and resolved before screening the remaining references. Only when both reviewers agreed that titles and abstracts met the inclusion criteria were the articles included. When a title and abstract could not be included with certainty, the full text of the article was obtained and then further evaluated. The remaining $90 \%$ was distributed among the reviewers in even parts. Following the initial screening process, full-text articles were 


\section{ACCEPTED MANUSCRIPT}

obtained. Further inclusion and exclusion criteria were then applied. Papers were only included in the meta-analysis if they were: RCTs; had an intervention duration of at least 2 weeks and reported baseline data for all outcome measures. Non-RCTs, uncontrolled trials or trials reporting insufficient or unclear data were excluded. Data was extracted from each study and organized in a Microsoft Access database file (Microsoft Corp, Redmond, WA, USA).

\section{Data synthesis}

When growth was measured at different time points within the same population, we used the measures as different estimations (Hamadani et al. 2001; Heinig et al. 2006; Sur et al 2003). One study reported data separately for boys and girls (Walravens et al. 1989). One study report data from two groups of infants (stunted and non stunted) and also these were treated as two different estimations within the meta-analysis (Umeta et al. 2000). Different estimations were also considered for the following studies: the study of Osendrap et al. 2002 that analyzed three groups of infants (all, infants with low serum $\mathrm{Zn}<9.18 \mu \mathrm{mol} / \mathrm{L}$, and infants with normal serum $\mathrm{Zn}>$ $9.18 \mu \mathrm{mol} / \mathrm{L}$ ) and the study of Arsenault et al. 2008 that assessed two groups ( $\mathrm{Zn}$ intake in a liquid supplement and in a fortified porridge).

If dietary intake of $\mathrm{Zn}$ (in addition to the intervention) was not reported in the RCTs we imputed a value of $1.3 \mathrm{mg} /$ day, the mean dietary intake level of the RCTs that did report dietary Zn intake. As mean baseline growth parameters were infrequently reported in the RCTs, most of the RCTs assumed no differences in baseline measures $(n=16)$. Arsenault and Rivera et al. (2008; 1998) performed an adjustment for initial differences. Only the study of Bates et al. (Bates et al. 1993) failed to report anything regarding this matter. 


\title{
ACCEPTED MANUSCRIPT
}

\section{Exposure and outcome and other covariates assessment:}

The influence of $\mathrm{Zn}$ intake on growth parameters was considered in the overall meta-analysis. From each select growth study, final measures were assessed: Weight, Length, MUAC, Head circumference, WAZ, LAZ and WLZ in all the included studies.

Other variables were also taken into account as possible effect modifiers. We considered doses of $\mathrm{Zn}$ intake ( 1 to $4 \mathrm{mg}, 4.1$ to $8 \mathrm{mg}, 8.1$ to $12 \mathrm{mg}$ and $>12.1 \mathrm{mg}$ ), intervention duration (1 to 3 weeks, 4 to 20 weeks and > 20 weeks), nutritional situation (healthy, nutritionally at risk and poor nutritional status) and risk of bias (low, moderate or high).

\author{
Assessment of nutritional situation in included studies \\ Poor nutritional status was defined as infants with low birth weight during their first year, \\ undernourished or current growth retardation evidenced by a WAZ and LAZ scores below -2; \\ nutritionally at risk was defined as infants who lived in low-income families with a low \\ socioeconomic situation.
}

\section{Assessment of risk of bias in included studies}

Risk of bias was assessed in order to evaluate the quality of the studies included. The following indicators of internal validity specific to the RCT methodology were collected during data extraction: 1) method of sequence generation 2) adequate allocation, 3) blinding, 4) number of participants at start, dropouts and dropout reasons, 5) outcome data complete, 6) funder adequate, 7) other potential funding bias. Based on these indicators, two reviewers assessed the 


\section{ACCEPTED MANUSCRIPT}

overall risk of bias. Disagreements were resolved by discussion. The criteria for judging these indicators were adapted from the Cochrane Handbook for Systematic Reviews (Higgins JPT \& Green S 2009).

\section{Statistical analysis}

Mean and standard deviation (SD) or standard errors (SE) of the outcome (Weight, Length, MUAC, Head circumference, WAZ, LAZ and WLZ) were assessed. From the mean and SD of each study, beta values $(\beta)$ and their SE were calculated because the statistical model that we used to estimate the relation between $\mathrm{Zn}$ intake ( $\mathrm{x}$-variable) and growth (y-variable) is based on the assumption that this intake-growth linear relationship is a logarithmic function and that both intake and growth follow a log-normal distribution (the natural logarithm of intake and growth have a normal distribution). Thus, the expected value of the growth score is expressed as:

$\mu y=\beta * \mu x+$ intercept

where $\mu y$ represents the mean of the natural logarithm of the $y$-variable (= growth score), $\beta$ represents the regression coefficient, and $\mu \mathrm{x}$ represents the mean of the natural logarithm of the $\mathrm{x}$-variable (= Zn intake).

This shape of this linear relationship on the $\log _{\mathrm{e}}-\log _{\mathrm{e}}$-scale corresponds to a monotonic concave function on the original scale for $\beta<1$. This shape is assumed to be realistic for the biological relationship between $\mathrm{Zn}$ intake and growth parameters. As the true dose-response curve is unknown, this approximation provides a practical methodology to estimate the dose-response relationship. 


\section{ACCEPTED MANUSCRIPT}

The method used to systematically review differences was a formal meta-analysis (Greenland 1998).

Procedures of formal meta-analysis have been applied to combine the results from previously reported studies (Dickersin 2002).

A random-effects model was considered to be more appropriate than a fixed-effects model. We used the DerSimonian and Laird's (DerSimonian \& Laird 1986) to pool the estimates of betas across studies. Under this model, the pooled effect was the beta in the growth parameters (Weight, Length, MUAC, Head circumference, WAZ, LAZ and WLZ), for an increment of 1 unit in $\mathrm{Zn}$ intake. A pooled beta estimate was calculated as a weighted average of the beta reported in each study.

The formula we used to estimate the weighted effect size was (Hedges 1982):

$\beta$ pooled $=\sum \beta i$ wi $/ \sum w i$

where $\beta$ pooled is the pooled estimate of the beta in growth parameters; the weight (wi) of each study was computed as:

$w i=1 / V i+\tau^{2}$

where $V$ is the variance of each study and $\tau^{2}$ is the inter-study variance.

Besides this, we calculated a 95\% CI for the pooled estimated of effect size:

$95 \% \mathrm{CI}=\beta$ pooled $\pm(1.96 \times \mathrm{SE}$ pooled $)$

where SE is the standard error of the pooled estimate (Greenland 1998).

A test of heterogeneity was calculated, estimating Q statistics, which follows a chi-square distribution with degrees of freedom $n-1, n$ being the number of studies included in the analysis. The $\mathrm{I}^{2}$ Index measures the extent of the heterogeneity. A low $P$ value for this statistic (lower than 


\section{ACCEPTED MANUSCRIPT}

0.05) indicates the presence of heterogeneity, which somewhat compromises the validity of the pooled estimates (Takkouche et al. 1999). Because significant heterogeneity was clearly evident in the pooled beta estimates for Length studies, we evaluated potential sources of heterogeneity by linear meta-regressions (Greenland 1998). We fitted a meta-regression using the duration of the intervention, the doses of $\mathrm{Zn}$ intake, the risk of bias and the nutritional situation as independent variables. The betas obtained in each study for the Length parameter according to $\mathrm{Zn}$ intake were used as the dependent variable.

Statistical differences in multivariate adjusted mean beta values between each possible heterogeneity sources were determined by analysis of covariance ANCOVA. Additionally we carried out additional meta-analyses by subgroups considering only those groups which provided significant values in the meta-regression.

Sensitivity analyses were also conducted. We excluded the studies considered outliers and recalculated the pool estimate of the beta in each growth parameter.

Microsoft Excel Version (7.0), SPSS 10.0 for Windows and Review Manager 5.1, were used to conduct the statistical analyses.

\section{Results}

Five thousand five hundred articles were identified in the initial search strategy. After applying the exclusion/inclusion criteria, 344 articles from the search appeared to be potentially relevant. After applying the additional eligibility criteria and grouping the studies by outcome, nineteen RCTs (38 estimations) were selected for the growth meta-analysis (Arsenault et al. 2008; Bates 


\section{ACCEPTED MANUSCRIPT}

et al. 1993; Berger et al. 2006; Dijkhuizen et al. 2001; Fischer Walker et al. 2009; Gardner et al. 2005; Hamadani et al. 2001; Heinig et al. 2006; Lind et al. 2004; Meeks Gardner et al. 1998; Müller et al. 2003; Ninh et al. 1996; Olney et al. 2006; Osendarp et al. 2002; Rivera et al. 1998; Sur et al. 2003; Umeta et al. 2000; Walravens et al. 1989; Wasantwisut et al. 2006). (Fig. 1)

Descriptive characteristics of the studies included in the meta-analysis are presented in Table 2. Of the nineteen studies included, only twelve comply strictly with the age infants ( 0 to 12 months) (Arsenault et al. 2008; Berger et al. 2006; Dijkhuizen et al. 2001; Fischer Walker et al. 2009; Heinig et al. 2006; Lind et al. 2004; Olney et al. 2006; Osendarp et al. 2002; Rivera et al. 1998; Sur et al. 2003; Umeta et al. 2000; Wasantwisut et al. 2006). The other seven studies included this age among their sample, but did not clarify how many are actually aged 0 to 12 months (Bates et al. 1993; Gardner et al. 2005; Hamadani et al. 2001; Meeks Gardner et al. 1998; Müller et al. 2003; Ninh et al. 1996; Walravens et al. 1989). None of the ages extended beyond 27 month, except Gardner et al. and Ninh et al. $(2005 ; 1996)$, which included children up to 30 and 36 months respectively.

Four studies were conducted in Latin America and the Caribbean, two in North America, nine in Asia and four in Africa. The duration of the interventions ranged from 2 to 60 weeks. Some studies assessed growth parameters at several time points within the study (Hamadani et al. 2001; Heinig et al. 2006; Sur et al. 2003). Doses of Zn intake ranged from 1.78 to $20 \mathrm{mg}$ per day. The nutritional situation of infants also varied between studies: six studies were conducted in healthy infants (Bates et al. 1993; Heinig et al. 2006; Lind et al. 2004; Osendarp et al. 2002; 


\section{ACCEPTED MANUSCRIPT}

Umeta et al. 2000; Wasantwisut et al. 2006), six studies were conducted on infants who were nutritionally at risk (Arsenault et al. 2008; Berger et al. 2006; Fischer Walker et al. 2009; Müller

et al. 2003; Rivera et al. 1998; Walravens et al. 1989), and seven studies were conducted on infants with poor nutritional status (Dijkhuizen et al. 2001; Gardner et al. 2005; Hamadani et al. 2001; Meeks Gardner et al. 1998; Ninh et al. 1996; Olney et al. 2006; Sur et al. 2003). The risk of bias varied also between studies: six studies had a high risk of bias, seven had a moderate risk and six showed a low risk of bias.

Differences in Growth outcomes (Weight, Length, MUAC, Head Circumference, WAZ, LAZ and WLZ) according to Zn intake in each particular study and in the pooled analyses are showed in Figures 2 to 8. Zn intake was not associated to Weight, Length, MUAC, Head Circumference and LAZ in the pooled analyses. However, $\mathrm{Zn}$ intake had a positive and statistically effect on WAZ $(\beta=0.06 ; 95 \% \mathrm{CI} 0.02$ to 0.10$)$ and $\mathrm{WLZ}(\beta=0.05 ; 95 \% \mathrm{CI} 0.01$ to 0.08$)$.

Since we applied a base- $e$ logarithmic transformation on the $\mathrm{Zn}$ intake and growth parameters before calculation of the study-specific $\beta$ 's, the overall $\beta$ represents the difference in the $\log _{\mathrm{e}}$ transformed predicted value of WAZ and WLZ for each one-unit difference in the $\log _{\mathrm{e}}$ transformed value in $\mathrm{Zn}$ intake. Therefore, an overall $\beta$ of 0.06 means that for every doubling in $\mathrm{Zn}$ intake, the difference in WAZ is $2^{\hat{\beta}}\left(2^{0.06}=1.04\right)$. For an overall $\beta$ of 0.05 , the difference in WLZ is 1.035 . That means that a person with a double intake of $\mathrm{Zn}$ has aproximately $4 \%$ higuer WAZ and WLZ than a person with the half intake. (Fig. 9, 10)

Excepting for Length $\left(\mathrm{I}^{2}=45 \%, \mathrm{p}=0.03\right)$, heterogeneity was not present in any analysis. In order to investigate which variables may be potential effect modifiers on Length, we performed a 


\section{ACCEPTED MANUSCRIPT}

meta-regression (Table 3). The effect of Zn intake on Length changed depending on the duration of the intervention and the dose $(\mathrm{p} A N C O V A=0.008$ and 0.023$)$ respectively.

Table 4 shows the results of Length analyses after stratifying the studies according to the effect modifiers identified in the meta-regression. After stratifying by duration of the intervention and by dose, the heterogeneity disappeared. At short time (4 to 20 weeks), $\mathrm{Zn}$ intake was positively associated with length values $(\beta=0.01$; CI $95 \% 0$ to 0.02$)$. However, no effect was found when supplementation lasted for more than 20 weeks $(\beta=-0.001$; CI $95 \%-0.003$ to 0.002$)$. At medium doses of $\mathrm{Zn}$ (4.1 to $8 \mathrm{mg} /$ day), $\mathrm{Zn}$ intake was positively associated with length values $(\beta=0.003$; CI 95\% 0 to 0.01). Nevertheless, the effect magnitude was small. However, no effect was found at low or high doses of $\mathrm{Zn}$ ( 1 to 4 or $>12 \mathrm{mg} / \mathrm{day})(\beta=0$; CI $95 \%-0.01$ to 0.004 and $\beta=0.01$; CI $95 \%-0.02$ to 0$)$ respectively.

The results of the sensitivity analyses are shown in Table 5. The study of Osendrap et al. (b) (2002), Walravens et al. (a) and Walravens et al. (b) (1989) were considered as outliers in the analysis of weight because the limits of beta were very wide (from CI 95\% 0.01 to 0.23; CI 95\% -0.04 to 0.10 and CI $95 \%-0.04$ to 0.10 ) respectively. When we excluded these studies, the null association previously seen remained. In WAZ studies the study of Sur et al. (d, e, f, g, h, I, j, k, 1) (2003) were considered as outliers for the same reasons. When we excluded these studies, we observed an attenuation of the positive effect of $\mathrm{Zn}$ supplementation on WAZ ( $\beta=0.03$; CI 95\% 0 to 0.07 ). The study of Osendrap et al. (b) (2002) was considered as an outlier in the analysis of Length. When we excluded this study, the null association previously seen persisted and also the heterogeneity $\left(\mathrm{I}^{2}=47 \% ; \mathrm{p}=0.03\right)$. 


\section{ACCEPTED MANUSCRIPT}

\section{Discussion}

Our results indicate that $\mathrm{Zn}$ supplementation increases some growth parameters in infants. $\mathrm{Zn}$ intake had a positive and statistically effect on WAZ $(\beta=0.06 ; 95 \% \mathrm{CI} 0.02$ to 0.10$)$ and WLZ ( $\beta$ $=0.05 ; 95 \% \mathrm{CI} 0.01$ to 0.08$)$. We only found significant heterogeneity while analysing length $\left(\mathrm{I}^{2}\right.$ $=45 \%, \mathrm{p}=0.03)$. After stratifying by several factors, heterogeneity disappeared.

To our knowledge, this meta-analysis is the only in providing an estimate of the dose-response relationship of $\mathrm{Zn}$ intake and growth parameters in infants aged 1-12 months. An infant with a $\mathrm{Zn}$ intake of $10 \mathrm{mg} /$ day has a WAZ and WLZ that is $4 \%$ higher than an infant who has a $\mathrm{Zn}$ intake of $5 \mathrm{mg} / \mathrm{day}$. However, interpretation of these results should be carefully considered for a number of reasons. It is a well acknowledged that when many statistical comparisons are carried out, one or more might reach significance due to chance alone (Bland \& Altman 1995). Although meta-analysis are increasingly used to consolidate results from multiple studies of the same topic and to develop evidence-based policies for clinical practice and public health programmes, the reliability of reached conclusions depends on the methodological quality of the original studies, the appropriateness of the study inclusion criteria, the thoroughness of the review and the synthesis of information (Brown et al. 2002). It is unlikely that confounding factors might have

affected our results since all the studies included in our meta-analyses are RCTs. However, if some baseline differences were observed because any failure in the randomize process, several authors performed an adjustment of initial differences (Arsenault et al. 2008 and Rivera et al. 1998). Other authors assumed no initial differences. The only exception was Bates et al (1993) that did not mention anything regarding this matter. 


\section{ACCEPTED MANUSCRIPT}

A limitation of this study was the small amount of studies that were eligible for inclusion in this meta-analysis. Although nineteen RCTs of the effect of Zn supplementation on infant's growth were included, for the association between $\mathrm{Zn}$ intake and head circumference the meta-analysis only included 4 studies which led to a reduction of the statistical power to detect significant differences.

Age of the study populations considered in this meta-analysis was another important point. We believe that there was no reason to exclude any study that did not adhere exclusively to the group of 0 to 12 months of age. For this reasons, we took into account all the studies which included this age group in the study, even if they were not analysed according to their age group (Bates et al. 1993; Gardner et al. 2005; Hamadani et al. 2001; Meeks Gardner et al. 1998; Müller et al. 2003; Ninh et al. 1996; Walravens et al. 1989) and assumed the consequences of this possible bias.

The small magnitude of effect that we observed might be due to some effect modifiers that should be considered whenever the effect of $\mathrm{Zn}$ deficiency on growth is being evaluated. Those include factors in close relation to infancy such as prematurity, low birth-weight (LBW), breastfeeding, protein energy malnutrition, infectious morbidity, poverty, and social deprivation, the pre-existing $\mathrm{Zn}$ status of the study subjects; and others directly related to $\mathrm{Zn}$ such as content and bioavailability of $\mathrm{Zn}$ in local diets. Moreover, methodological aspects of these studies, such as variations in the dose, chemical form, method of administration of $\mathrm{Zn}$ and duration of supplementation, may have influenced our results (Brown et al. 2002). Some of these aspects were analysed in the sub-groups analyses of the meta-analysis. Duration of the intervention in some studies was other possible explication to the small magnitude of the effect founded. Time 


\section{ACCEPTED MANUSCRIPT}

of the intervention appears to be too short to obtain a positive impact on growth (Heinig et al. 2006; Lind et al. 2004; Meeks Gardner et al. 1998; Sur et al. 2003). However, this becomes more relevant when studies are conducted in LBW infants because the low weight together with the immaturity associated with premature infants requires adjustment of gestational age with chronological age for proper assessment of catch-up growth (Rugolo 2005). This is the case of the Meeks Gardner and Sur's studies (Meeks Gardner 1998; Sur et al. 2003) which were conducted in infants with a poor nutritional status. Nonetheless, on healthy infants Lind et al. (2004) reported improvements in growth in a 3 month period. Opposite results were obtained by Bates et al. and Heinig et al. $(1993 ; 2006)$ which failed to observe a positive effect in longer periods of time. Also Rivera et al. and Umeta et al. (1998; 2000) found that MUAC did not change due to the extension of the supplementation period which was apparently too short to find any measurable effect. Thus, clinical trials are required to analyze the long-term effects on growth of $\mathrm{Zn}$ supplementation before reaching significant conclusions.

Other consideration to take into account is that the data from our meta-analysis was obtained generally from countries in a developing stage and included data from LBW and malnourished infants which might have resulted in the poor effect we found. Several studies have been carried out worldwide and many of these showed a positive effect of $\mathrm{Zn}$ supplementation on growth among groups of children who were nutritionally disadvantaged in some way, including stunted children (Walravens et al. 1989; Wasantwisut et al. 2006), and in particular among malnourished children (Arsenault et al. 2008; Ninh et al. 1996; Rivera et al. 1998). On the other hand, there was no growth response to supplementation in healthy Gambian nor healthy USA infants (Bates

et al. 1993; Heinig et al. 2006). A meta-analysis of 25 studies (Brown et al. 1998) of $\mathrm{Zn}$ 


\section{ACCEPTED MANUSCRIPT}

supplements on growth of children in developing countries found smaller but significant effects on growth (an effect size of +0.22 for height and +0.26 for weight increments). However, an updated version of that meta-analysis (Brown et al. 2002) based on 33 RCT, showed a highly significant aggregate effect size of 0.350 (95\% CI: 0.189, 0.511) for height, 0.309 (95\% CI: $0.178,0.439$ ) for weight, and $\approx 0$ for WLZ increments. Thus $\mathrm{Zn}$ supplementation on child growth has been studied extensively in developing countries, but relatively little information is available from industrialized ones (Brown et al. 2002). Therefore, it is unclear whether children in industrialized countries would benefit from increased $\mathrm{Zn}$ intakes.

In conclusion, our meta-analyses provided us an estimate of the dose-response relation between $\mathrm{Zn}$ intake and some growth's parameters (WAZ and WLZ) in infant population. These data can be used as complementary evidence for underpinning $\mathrm{Zn}$ reference values, although restrictions on extrapolation of our results to other populations should be acknowledged mainly to developed populations.

For the others growth's parameters included in the meta-analyses, no effect was found. Further standardized research is urgently needed to reach evidence-based conclusions to clarify the role of $\mathrm{Zn}$ supplementation upon infant growth mainly in Western populations.

ACKNOWLEDGEMENTS: This research was undertaken as an activity of the European Micronutrient Recommendations Aligned (EURRECA) Network of Excellence (http://www.eurreca.org), funded by the European Commission Contract Number FP6 036196-2 


\section{ACCEPTED MANUSCRIPT}

(FOOD). The original concept of the systematic review was undertaken by the EURRECA Network and coordinated by partners based at Wageningen University (WU), the Netherlands and the University of East Anglia (UEA), United Kingdom. Susan Fairweather-Tait (UEA), Lisette de Groot (WU), Pieter van' t Veer (WU), Kate Ashton (UEA), Amélie Casgrain (UEA), Adriënne Cavelaars (WU), Rachel Collings (UEA), Rosalie Dhonukshe-Rutten (WU), Esmée Doets (WU), Linda Harvey (UEA) and Lee Hooper (UEA) designed and developed the review protocol and search strategy.

The authors would also like to thank Lisa Verberne, Catarina Oliveira, Noé Brito García, María del Rosario García Luzardo, Noemí Rodríguez Calcines and Yurena García Santos for their assistance with the selection of studies and the extraction of data.

The authors' responsibilities were as follows: NM: analysed the data and wrote the manuscript, NM, DAJ, LSA and WMM: reviewed the papers and contributed to the selection of the papers and the data extraction, SVA: provided support in data-analysis, FLD, HSP, PQL, RC, LN, MHV and SML provided significant advice. All authors directly participated in the planning, execution or analysis of the study and reviewed the manuscript.

CONFLICT OF INTEREST: Authors declare that they have no conflicts of interest. 


\section{ACCEPTED MANUSCRIPT}

\section{References}

Arsenault JE, López de Romaña D, Penny ME, Van Loan MD, Brown KH. (2008). Additional zinc delivered in a liquid supplement, but not in a fortified porridge, increased fat-free mass accrual among young Peruvian children with mild-to-moderate stunting. 138: 108-14.

Ashwell M, Lambert JP, Alles MS, Branca F, Bucchini L, Brzozowska A, de Groot LC, Dhonukshe-Rutten RA, Dwyer JT, Fairweather-Tait S, Koletzko B, Pavlovic M, Raats MM, Serra-Majem L, Smith R, van Ommen B, Veer P, von Rosen J, Pijls LT; EURRECA Network. (2008). How we will produce the evidence-based eurreca toolkit to support nutrition and food policy. Eur J Nutr. 47, 2-16.

Bates CJ, Evans PH, Dardenne M, Prentice A, Lunn PG, Northrop-Clewes CA, Hoare S, Cole TJ, Horan SJ, Longman SC, Stirling D, Aggett PJ. (1993). A trial of zinc supplementation in young rural Gambian children. Br J Nutr. 69, 243-55.

Berger J, Ninh NX, Khan NC, Nhien NV, Lien DK, Trung NQ, Khoi HH. (2006). Efficacy of combined iron and zinc supplementation on micronutrient status and growth in Vietnamese infants. Eur J Clin Nutr. 60, 443-54.

Bland JM \& Altman DG. (1995). Multiple significance tests: the Bonferroni method. BMJ. 21, 310 (6973): 170. 


\section{ACCEPTED MANUSCRIPT}

Brown KH, Peerson JM, Allen LH. (1998). Effect of zinc supplementation on children's growth: a meta-analysis of intervention trials. Bibl Nutr Dieta. 54: 76-83.

Brown KH, Peerson JM, Rivera J, Allen LH. (2002). Effect of supplemental zinc on the growth and serum zinc concentrations of prepubertal children: a meta-analysis of randomized controlled trials. Am J Clin Nutr. 75, 1062-1071.

Chesters JK. (1978). Biochemical functions of zinc in animals. World Rev Nutr Diet. 32, 13564.

DerSimonian R, Laird N. (1986). Meta-analysis in clinical trials. Control Clin.Trials. 7, 177-188.

Dewey KG, Brown KH. (2003). Update on technical issues concerning complementary feeding of young children in developing countries and implications for intervention programs. Food Nutr Bull. 24: $5-28$

Dickersin K. (2002). Systematic reviews in epidemiology: why are we so far behind? Int. J. Epidemiol. 31, 6-12.

Dijkhuizen MA, Wieringa FT, West CE, Martuti S, Muhilal. (2001). Effects of iron and zinc supplementation in Indonesian infants on micronutrient status and growth. J Nutr. 131: 2860-5. 


\section{ACCEPTED MANUSCRIPT}

Fischer Walker CL, Ezzati M, Black RE. (2009). Global and regional child mortality and burden of disease attributable to zinc deficiency. Eur J Clin Nutr. 63: 591-7

Gardner JM, Powell CA, Baker-Henningham H, Walker SP, Cole TJ, Grantham-McGregor SM. (2005). Zinc supplementation and psychosocial stimulation: effects on the development of undernourished Jamaican children. Am J Clin Nutr. 82: 399-405.

Gibson RS, Ferguson EL, Smit Vanderkooy PD, MacDonald AC. (1989) Seasonal variations in hair zinc concentrations in Canadian and African children. Sc Total Environ. 84: 291-98.

Golden BE, Golden MHN. (1981). Trace elements: potential importance in human nutrition with particular reference to zinc and vanadium. Br Med Bull. 37: 31-6.

Greenland S. (1998). Meta-analysis. In Modern Epidemiology. eds. K.J. Rothman, \& S.S. Greenland; pp. 643-673. Philadelphia: Lippincott Raven.

Hamadani JD, Fuchs GJ, Osendarp SJ, Khatun F, Huda SN, Grantham-McGregor SM. (2001) Randomized controlled trial of the effect of zinc supplementation on the mental development of Bangladeshi infants. Am J Clin Nutr. 74: 381-6.

Hambidge KM. (1992). Zinc and diarrhea. Acta Paediatr Suppl. 381: 82-6. 


\title{
ACCEPTED MANUSCRIPT
}

Hedges LV. (1982). Estimation of effect size from a series of independent experiments. Psychol. Bull. 92: 490-499.

Heinig MJ, Brown KH, Lönnerdal B, Dewey KG. (2006). Zinc supplementation does not affect growth, morbidity, or motor development of US term breastfed infants at 4-10 mo of age. Am J Clin Nutr. 84: 594-601.

\author{
Hermoso M, Tabacchi G, Iglesia-Altaba I, Bel-Serrat S, Moreno-Aznar LA, García-Santos Y, \\ García-Luzardo Mdel R, Santana-Salguero B, Peña-Quintana L, Serra-Majem L, Moran VH, \\ Dykes F, Decsi T, Benetou V, Plada M, Trichopoulou A, Raats MM, Doets EL, Berti C, Cetin I, \\ Koletzko B. (2010). The nutritional requirements of infants. Towards EU alignment of reference \\ values: the EURRECA network. Maternal \& Child Nutrition. 6: 55-83.
}

Higgins JPT, Green S (editors). (2009). Cochrane Handbook for Systematic Reviews for Interventions Version $\quad$ 5.0.2. The Cochrane Collaboration; http://www.cochrane.org/training/cochrane-handbook

International Zinc Nutrition Consultative Group. (2004). Assessment of the risk of zinc status in populations and options for the control of zinc deficiency. Boston: International Nutrition Foundation for United Nations University Press. 


\section{ACCEPTED MANUSCRIPT}

Lind T, Lönnerdal B, Stenlund H, Gamayanti I, Djauhar I, Seswandhana R, Persson LA. (2004). A community-based randomized controlled trial of iron and zinc supplementation in Indonesian infants: effects on growth and development. Am J Clin Nutr. 80: 729-36.

MacDonald RS. (2000). The role of zinc in growth and cell proliferation. J Nutr. 130: 1500S-8S.

Matthys C, van 't Veer P, de Groot L, Hooper L, Cavelaars AE, Collings R, Donutske-Rutten R, Harvey LJ, Casgrain A, Rollin F, Contor L. (2011). Eurreca's approach for estimating micronutrient requirements. International J Vit and Nutr Res. 81: 256-263.

Meeks Gardner J, Witter MM, Ramdath DD. (1998). Zinc supplementation: effects on the growth and morbidity of undernourished Jamaican children. Eur J Clin Nutr. 52: 34-9.

Müller O, Garenne M, Reitmaier P, Van Zweeden AB, Kouyate B, Becher H. (2003). Effect of zinc supplementation on growth in West African children: a randomized double-blind placebocontrolled trial in rural Burkina Faso. Int J Epidemiol. 32: 1098-102.

Ninh NX, Thissen JP, Collette L, Gerard G, Khoi HH, Ketelslegers JM. (1996). Zinc supplementation increases growth and circulating insulin-like growth factor I (IGF-I) in growthretarded Vietnamese children. Am J Clin Nutr. 63: 514-9.

Olney DK, Pollitt E, Kariger PK, Khalfan SS, Ali NS, Tielsch JM, Sazawal S, Black R, Allen LH, Stoltzfus RJ. (2006). Combined iron and folic acid supplementation with or without zinc 


\section{ACCEPTED MANUSCRIPT}

reduces time to walking unassisted among Zanzibari infants 5- to 11-mo old. J Nutr. 136: 242734.

Osendarp SJ, Santosham M, Black RE, Wahed MA, van Raaij JM, Fuchs GJ. (2002). Effect of zinc supplementation between 1 and 6 mo of life on growth and morbidity of Bangladeshi infants in urban slums. Am J Clin Nutr. 76: 1401-8.

Rivera JA, Ruel MT, Santizo MC, Lönnerdal B, Brown KH. (1998). Zinc supplementation improves the growth of stunted rural Guatemalan infants. J Nutr. 128: 556-62.

Rugolo LM. (2005). Growth and developmental outcomes of the extremely preterm infant. J Pediatr (Rio J). 81: S101-10.

Ruz M, Solomons NW. (1990). Mineral excretion during acute, dehydrating diarrhea treated with oral rehydration therapy. Pediatr Res. 27: 170-5.

Ruz M, Cavan KR, Bettger WJ, Thompson L, Berry M, Gibson RS. (1991). Development of a dietary model for the study of mild zinc deficiency in humans and evaluation of some biochemical and functional indices of zinc status. Am J Clin Nutr. 53: 1295-303.

Shankar AH, Prasad AS. (1998). Zinc and immune function: the biological basis of altered resistance to infection. Am J Clin Nutr. 68: 447S-63S. 


\section{ACCEPTED MANUSCRIPT}

Sur D, Gupta DN, Mondal SK, Ghosh S, Manna B, Rajendran K, Bhattacharya SK. (2003). Impact of zinc supplementation on diarrheal morbidity and growth pattern of low birth weight infants in kolkata, India: a randomized, double-blind, placebo-controlled, community-based study. Pediatrics. 112: 1327-32.

Takkouche B, Cadarso-Suarez C, Spiegelman D. (1999). Evaluation of old and new tests of heterogeneity in epidemiologic meta-analysis. Am. J. Epidemiol. 150: 206-215.

The World Bank. (2006). Repositioning nutrition as central to development: a strategy for largescale action. Washington, DC: The World Bank.

Umeta M, West CE, Haider J, Deurenberg P, Hautvast JG. (2000). Zinc supplementation and stunted infants in Ethiopia: a randomized controlled trial. Lancet. 355: 2021-6.

Walravens PA, Hambidge KM, Koepfer DM. (1989). Zinc supplementation in infants with a nutritional pattern of failure to thrive: a double-blind controlled study. Pediatrics. 83: 532-38.

Wasantwisut E, Winichagoon P, Chitchumroonchokchai C, Yamborisut U, Boonpraderm A, Pongcharoen T, Sranacharoenpong K, Russameesopaphorn W. (2006). Iron and zinc supplementation improved iron and zinc status, but not physical growth, of apparently healthy, breast-fed infants in rural communities of northeast Thailand. J Nutr. 136: 2405-11. 


\section{ACCEPTED MANUSCRIPT}

Titles and abstracts identified from electronic search and screened Master Library of Zinc: $n=5500$

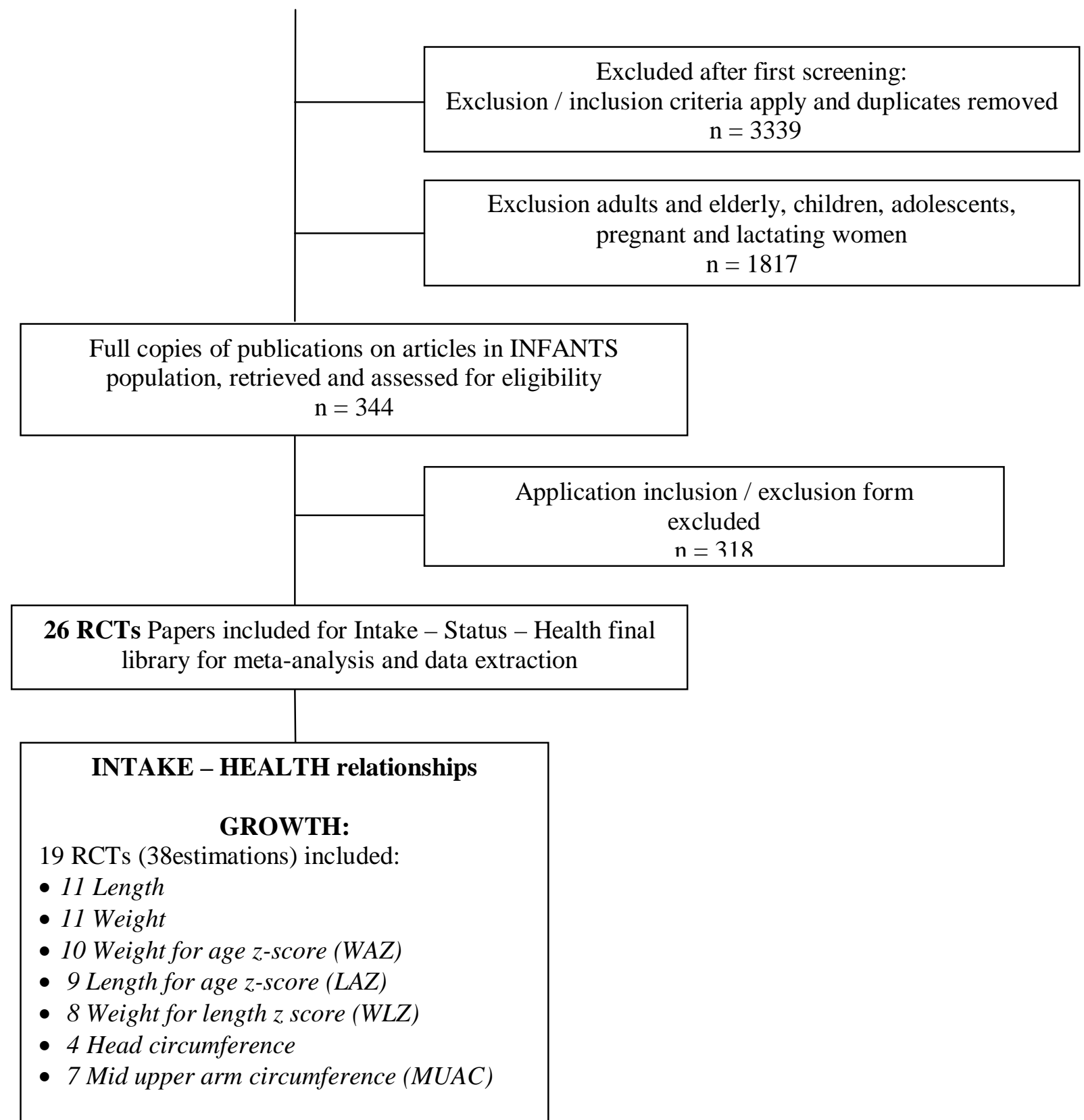

Figure 1: Flow diagram for the systematic review. 


\section{ACCEPTED MANUSCRIPT}

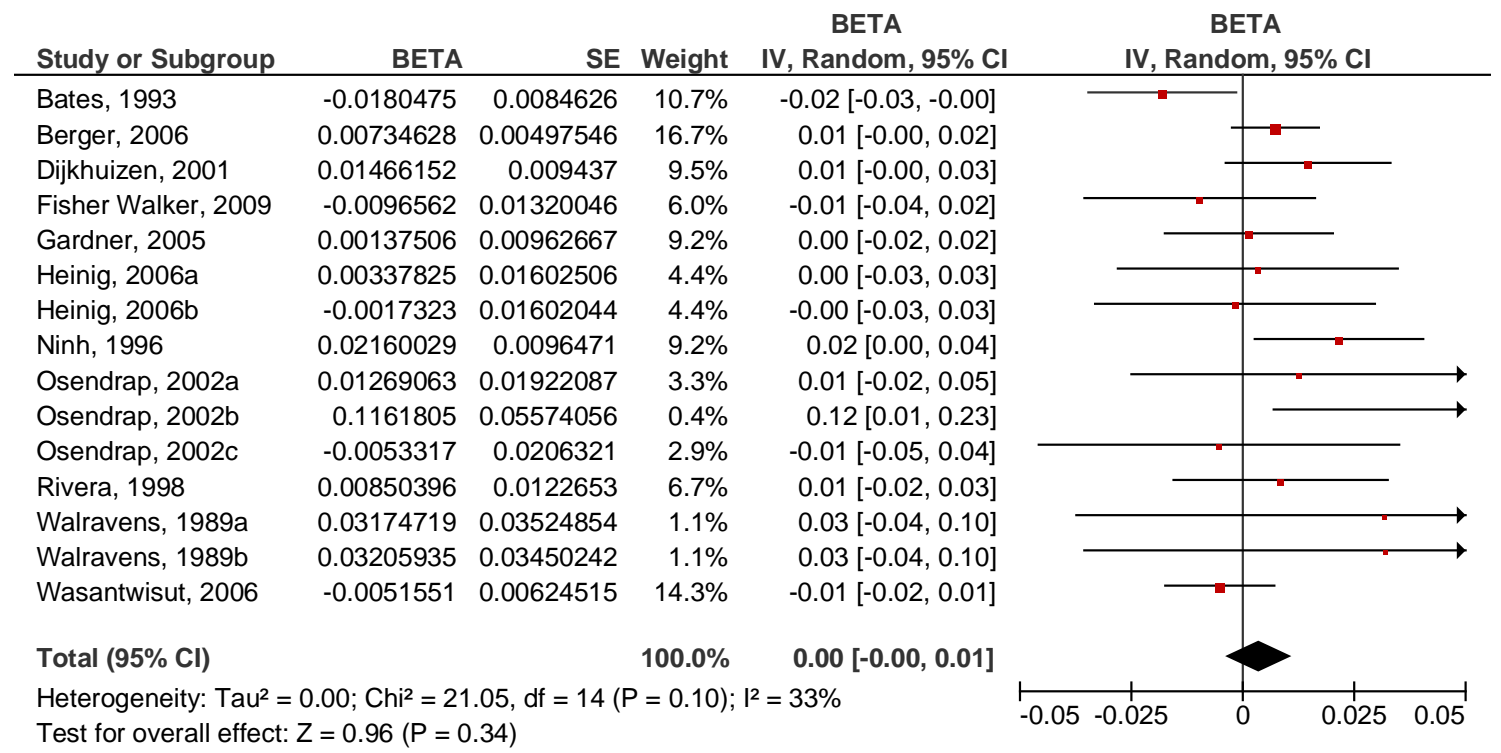

Figure 2: Forest plot of randomized controlled trials evaluating the effect of zinc intake on Growth (Weight) in infants. 


\title{
ACCEPTED MANUSCRIPT
}

\begin{tabular}{|c|c|c|c|c|c|}
\hline Study or Subgroup & BETA & SE & Weight & $\begin{array}{c}\text { BETA } \\
\text { IV, Random, } 95 \% \mathrm{Cl}\end{array}$ & $\begin{array}{c}\text { BETA } \\
\text { IV, Random, } 95 \% \mathrm{Cl}\end{array}$ \\
\hline Bates, 1993 & -0.00911733 & 0.00350464 & $10.1 \%$ & $-0.01[-0.02,-0.00]$ & $\because-$ \\
\hline Berger, 2006 & 0.00127531 & 0.00163496 & $16.6 \%$ & $0.00[-0.00,0.00]$ & . \\
\hline Dijkhuizen, 2001 & 0.00323455 & 0.00284444 & $12.2 \%$ & $0.00[-0.00,0.01]$ & $=$ \\
\hline Fisher Walker, 2009 & -0.00132211 & 0.00395489 & $8.9 \%$ & $-0.00[-0.01,0.01]$ & \\
\hline Gardner, 2005 & -0.00189339 & 0.00510542 & $6.5 \%$ & $-0.00[-0.01,0.01]$ & \\
\hline Heinig, 2006a & 0.00273816 & 0.00523651 & $6.3 \%$ & $0.00[-0.01,0.01]$ & \\
\hline Heinig, 2006b & 0.00094092 & 0.00493665 & $6.8 \%$ & $0.00[-0.01,0.01]$ & \\
\hline Ninh, 1996 & 0.00754716 & 0.00536704 & $6.1 \%$ & $0.01[-0.00,0.02]$ & \\
\hline Osendrap, 2002a & 0.0309756 & 0.01361784 & $1.3 \%$ & $0.03[0.00,0.06]$ & \\
\hline Osendrap, 2002b & 0.02833152 & 0.03556728 & $0.2 \%$ & $0.03[-0.04,0.10]$ & \\
\hline Osendrap, 2002c & 0.0204524 & 0.01450255 & $1.1 \%$ & $0.02[-0.01,0.05]$ & \\
\hline Rivera, 1998 & 0.00689355 & 0.00475003 & $7.1 \%$ & $0.01[-0.00,0.02]$ & \\
\hline Walravens, $1989 a$ & 0.03164554 & 0.0218218 & $0.5 \%$ & $0.03[-0.01,0.07]$ & \\
\hline Walravens, $1989 \mathrm{~b}$ & 0.00684012 & 0.02387138 & $0.4 \%$ & $0.01[-0.04,0.05]$ & \\
\hline Wasantwisut, 2006 & -0.00263837 & 0.00183544 & $15.9 \%$ & $-0.00[-0.01,0.00]$ & 4 \\
\hline Total $(95 \% \mathrm{Cl})$ & & & $100.0 \%$ & $0.00[-0.00,0.00]$ & \\
\hline \multicolumn{5}{|c|}{$\begin{array}{l}\text { Heterogeneity: } \mathrm{Tau}^{2}=0.00 ; \mathrm{Chi}^{2}=25.30, \mathrm{df}=14(P=0.03) ; \mathrm{I}^{2}=45 \% \\
\text { Test for overall effect: } Z=0.68(P=0.50)\end{array}$} & $-0.05-0.025$ \\
\hline
\end{tabular}

Figure 3: Forest plot of randomized controlled trials evaluating the effect of zinc intake on

\author{
Growth (Length) in infants.
}




\section{ACCEPTED MANUSCRIPT}

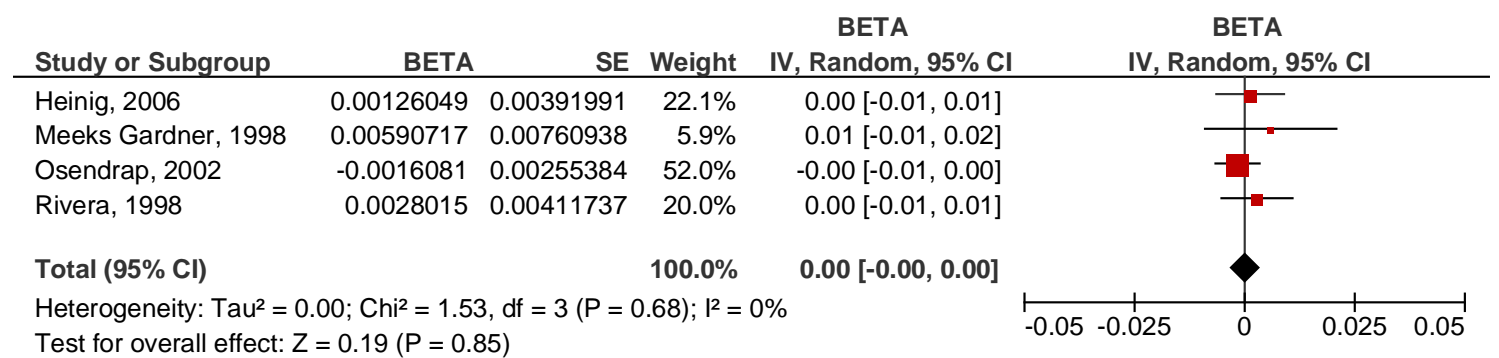

Figure 4: Forest plot of randomized controlled trials evaluating the effect of zinc intake on Growth (Head Circumference) in infants.

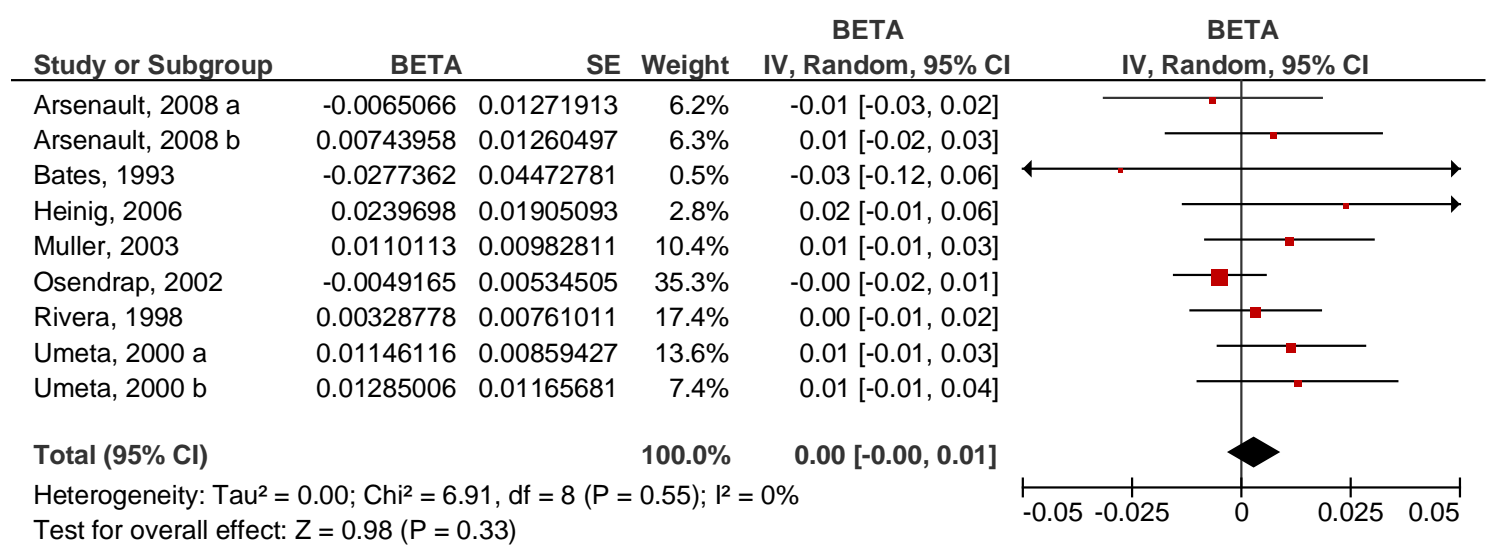

Figure 5: Forest plot of randomized controlled trials evaluating the effect of zinc intake on Growth (MUAC: Mid upper arm circumference) in infants. 


\section{ACCEPTED MANUSCRIPT}

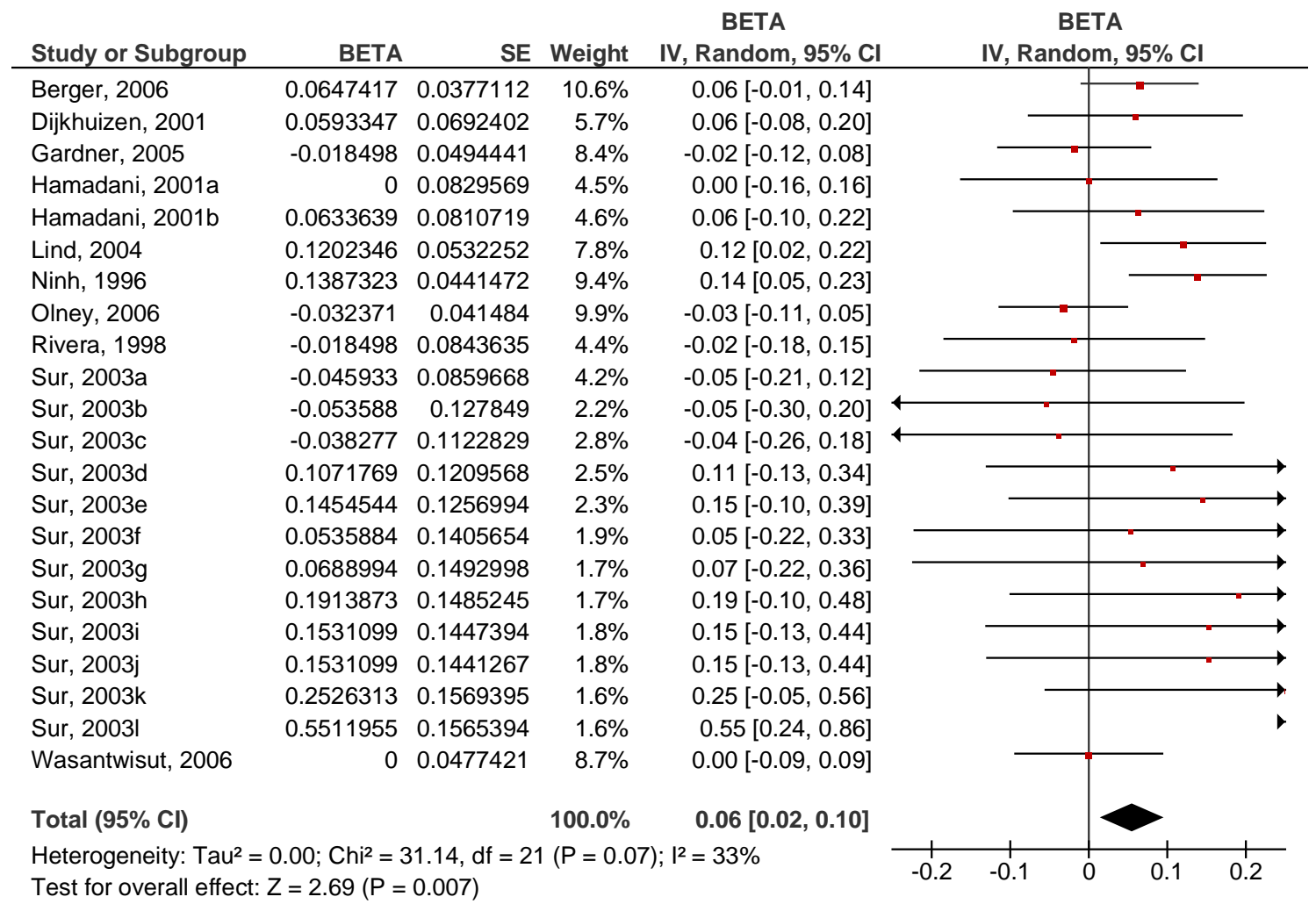

Figure 6: Forest plot of randomized controlled trials evaluating the effect of zinc intake on

Growth (WAZ: Weight for age $Z$ - score) in infants. 


\section{ACCEPTED MANUSCRIPT}

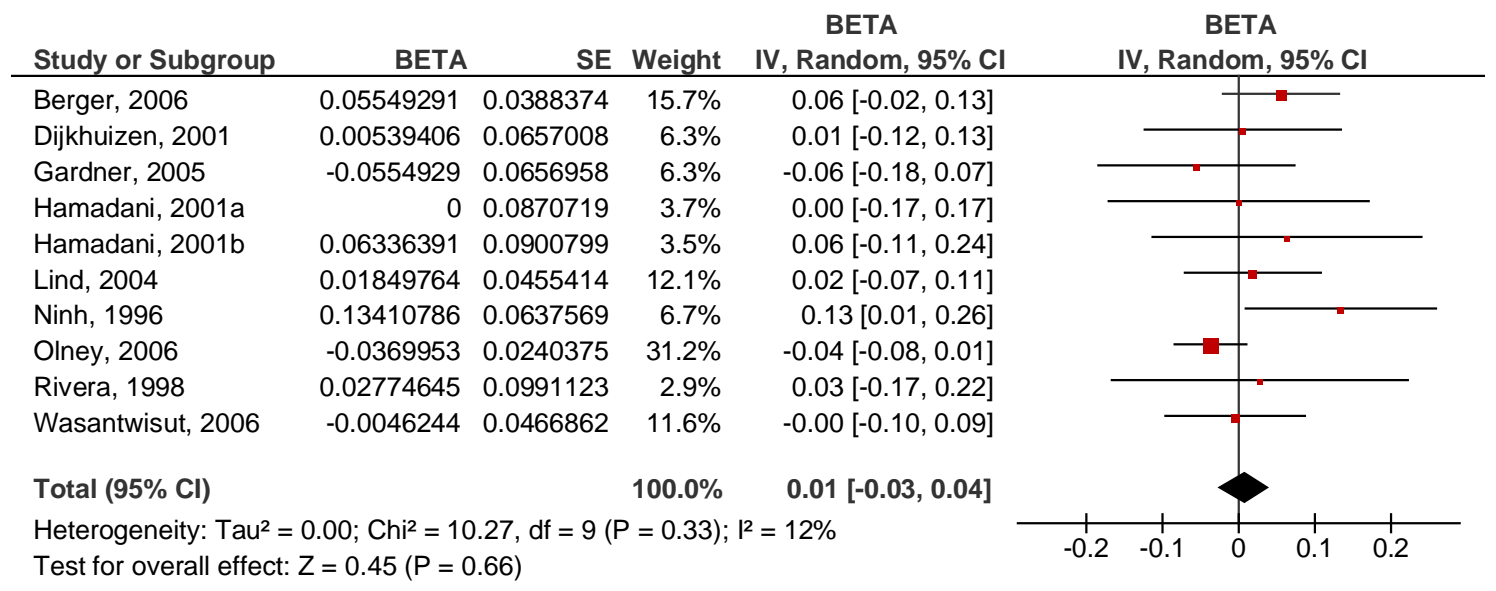

Figure 7: Forest plot of randomized controlled trials evaluating the effect of zinc intake on

Growth (LAZ: Length for age Z- score) in infants. 


\section{ACCEPTED MANUSCRIPT}

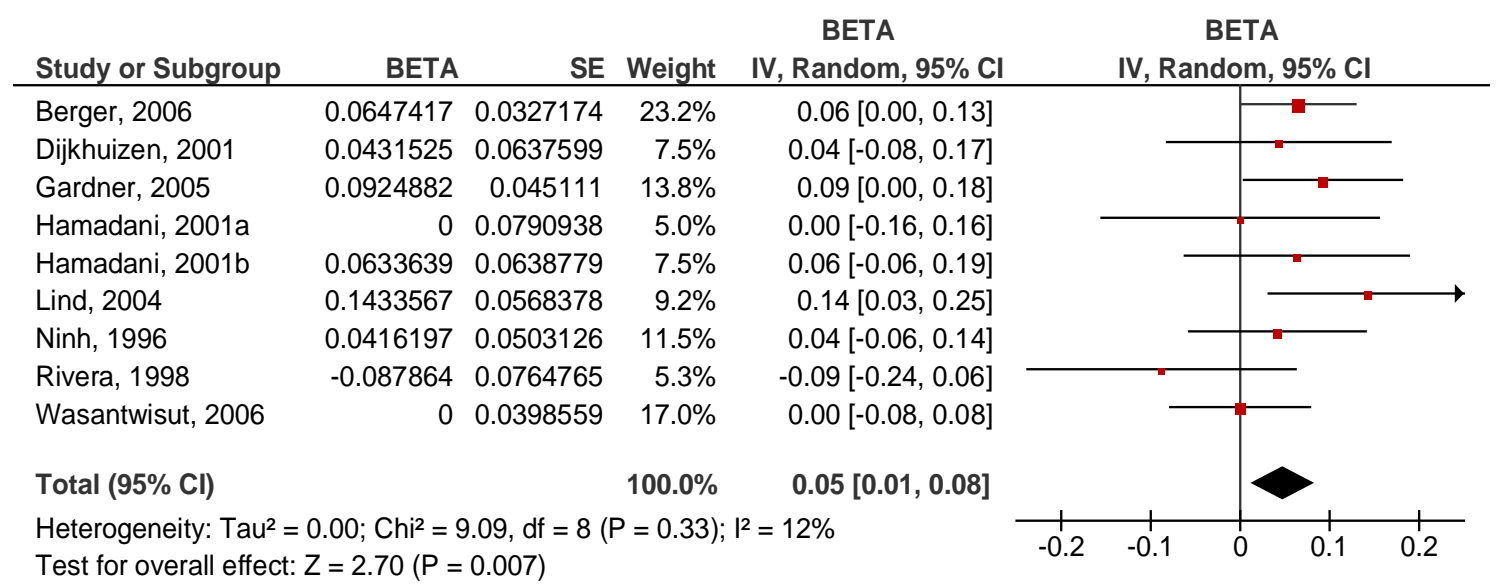

Figure 8: Forest plot of randomized controlled trials evaluating the effect of zinc intake on

Growth (WLZ: Weight for length Z- score) in infants. 


\section{ACCEPTED MANUSCRIPT}

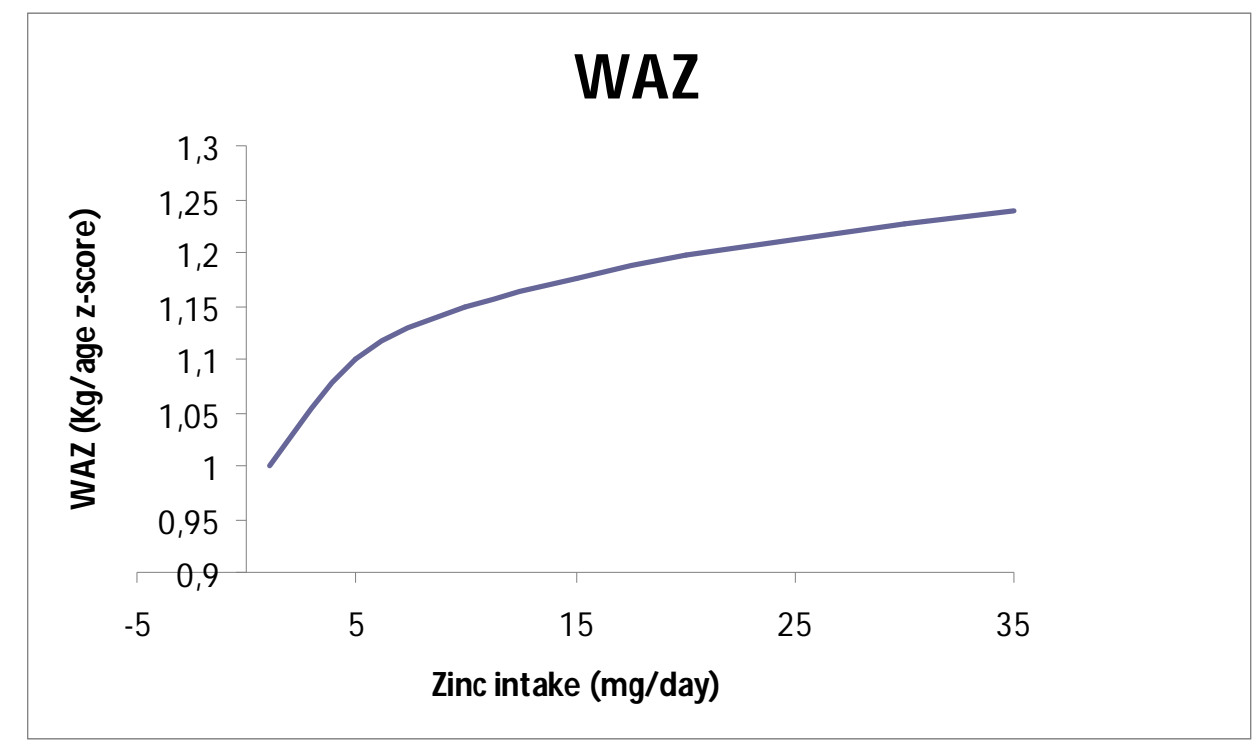

Figure 9: WAZ (Kg/age z-score) as a function of dietary zinc intake (mg/day), estimated by random effects meta-analyses of RCTs of infants. 


\section{ACCEPTED MANUSCRIPT}

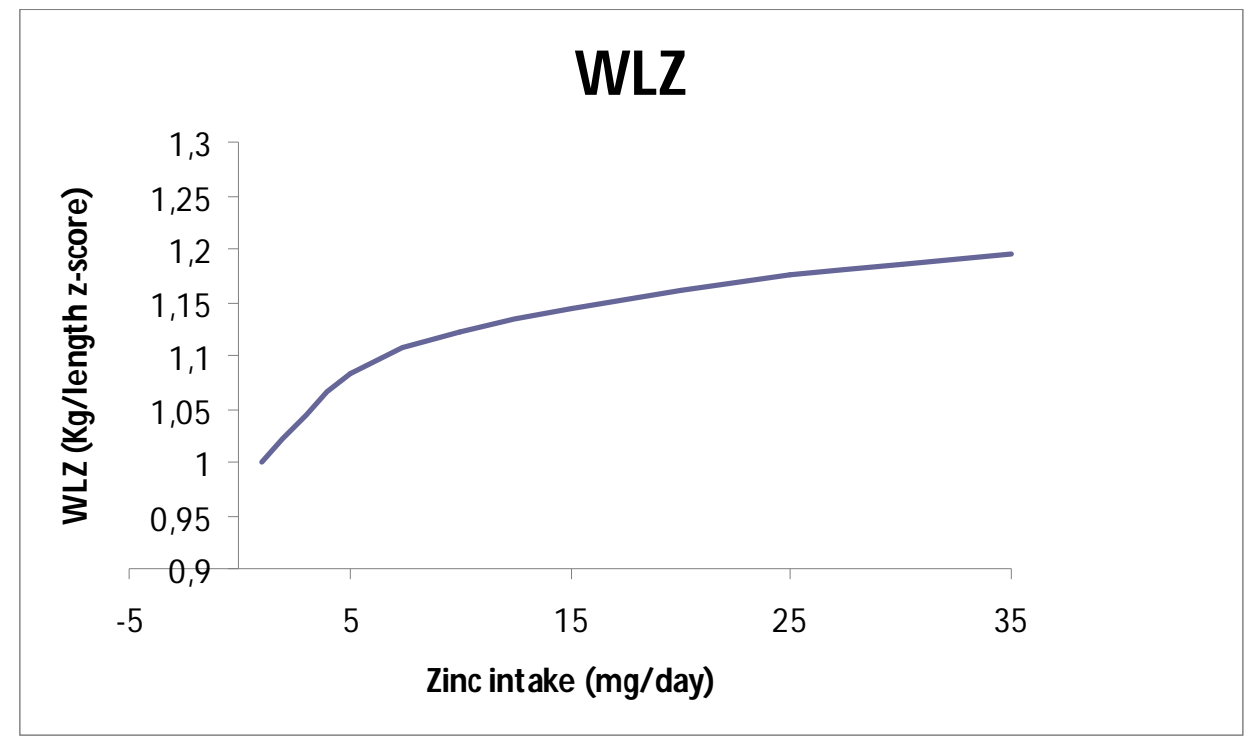

Figure 10: WLZ (Kg/Length z-score) as a function of dietary zinc intake (mg/day), estimated by random effects meta-analyses of RCTs of infants. 


\section{ACCEPTED MANUSCRIPT}

Table 1: Search strategy: MEDLINE February 2010

(MEDLINE home page. Available online: http://www.ncbi.nlm.nih.gov/pubmed/)

\begin{tabular}{|c|c|c|}
\hline No. & Search term & Results \\
\hline 1 & randomized controlled trial.pt. & 280,821 \\
\hline 2 & controlled clinical trial.pt. & 79,998 \\
\hline 3 & randomised.ab. & 196,604 \\
\hline 4 & placebo.ab. & 117,891 \\
\hline 5 & clinical trials as topic.sh. & 146,242 \\
\hline 6 & randomly.ab. & 145,491 \\
\hline 7 & trial.ab. & 203,467 \\
\hline 8 & randomised.ab. & 38,423 \\
\hline 9 & 6 or 3 or 7 or 2 or 8 or 1 or 4 or 5 & 734,511 \\
\hline 10 & (animals not (human and animals)).sh. & $4,482,479$ \\
\hline 11 & 9 not 10 & 642,665 \\
\hline 12 & $\begin{array}{l}\text { (cohort* or "case control*" or cross-sectional* or "cross sectional" or case- } \\
\text { control* or prospective or "systematic review" }^{*} \text { ").mp. }\end{array}$ & 768,885 \\
\hline 13 & $\begin{array}{l}\text { exp meta-analysis/ or expmulticenter study/ or follow-up studies/ or } \\
\text { prospective studies/ or intervention studies/ or epidemiologic studies/ or case- } \\
\text { control studies/ or exp cohort studies/ or longitudinal studies/ or cross-sectional } \\
\text { studies/ }\end{array}$ & $1,013,635$ \\
\hline 14 & 13 or 12 & $1,203,767$ \\
\hline 15 & 14 not 10 & $1,154,385$ \\
\hline 16 & 11 or 15 & $1,599,094$ \\
\hline 17 & ((zinc or zn or zinc sulphate or zinc gluconate or zinc acetate or methionine or & 16,681 \\
\hline
\end{tabular}




\section{ACCEPTED MANUSCRIPT}

zinc isotope*) adj3 (intake* or diet* or supplement* or deplet* or status or serum or plasma or leukocyte or concentration* or expos* or fortif* or urine or hair)).ti,ab.

18 Nutritional Support/ or Dietary Supplements/ or nutritional requirements/ or Breast feeding/ or exp infant food/ or bottle feeding/ or infant formula/

exp Nutritional Status/ or exp Deficiency Diseases/ or supplementation/ or diet supplementation/ or dietary intake/ or exp diet restriction/ or exp mineral intake/ or Diet/ or Food, Fortified/ or nutrition assessment/ or Nutritive Value/ 


\section{ACCEPTED MANUSCRIPT}

Table 2: Characteristics of the 19 (38 estimations) Growth studies included in the meta-analysis

\begin{tabular}{|c|c|c|c|c|c|c|c|c|c|c|}
\hline Author & $\begin{array}{l}\text { Study } \\
\text { year }\end{array}$ & Country & $\begin{array}{l}\text { Sample Age } \\
\text { range or } \\
\text { Mean }(\mathrm{SD})\end{array}$ & \multicolumn{2}{|c|}{ Number of infants (n) } & $\begin{array}{l}\text { Doses of } \\
\mathrm{Zn} / \text { day }\end{array}$ & $\begin{array}{l}\text { Time of } \\
\text { the } \\
\text { interventio } \\
n\end{array}$ & $\begin{array}{l}\text { Outcome } \\
\text { (measure) }\end{array}$ & $\begin{array}{l}\text { Nutriti } \\
\text { onal } \\
\text { situati } \\
\text { on }\end{array}$ & $\begin{array}{l}\text { Risk } \\
\text { of } \\
\text { bias }^{1}\end{array}$ \\
\hline $\begin{array}{l}\text { Arsenault } \\
\text { (a) (b) }\end{array}$ & 2008 & Peru & $\begin{array}{l}6 \text { to } 8 \\
\text { months }\end{array}$ & 4444 & $\begin{array}{l}36 \\
38\end{array}$ & $\begin{array}{l}3 \mathrm{mg} \text { in a } \\
\text { liquid } \\
\text { suppleme } \\
\text { nt } 3 \mathrm{mg} \text { in } \\
\text { a fortified } \\
\text { porridge }\end{array}$ & $24 \mathrm{w}$ & $\begin{array}{l}\text { Growth: } \\
\text { MUAC }\end{array}$ & $\begin{array}{l}\text { Nutriti } \\
\text { onally } \\
\text { at risk }\end{array}$ & $\begin{array}{l}\text { High } \\
\text { risk }\end{array}$ \\
\hline Bates & 1993 & Gambia & $\begin{array}{l}5.7 \text { to } 27 \\
\text { months }\end{array}$ & 50 & 53 & $20 \mathrm{mg}$ & $60 w$ & $\begin{array}{l}\text { Growth: } \\
\text { Weight - } \\
\text { Length } \\
\text { MUAC }\end{array}$ & $\begin{array}{l}\text { Health } \\
\mathrm{y}\end{array}$ & $\begin{array}{l}\text { High } \\
\text { risk }\end{array}$ \\
\hline Berger & 2006 & Vietnam & $\begin{array}{l}4 \text { to } 7 \\
\text { months }\end{array}$ & 195 & 191 & $10 \mathrm{mg}$ & $24 \mathrm{w}$ & $\begin{array}{l}\text { Growth: } \\
\text { Weight - } \\
\text { Length } \\
\text { WAZ - } \\
\text { LAZ - WLZ }\end{array}$ & $\begin{array}{l}\text { Nutriti } \\
\text { onally } \\
\text { at risk }\end{array}$ & $\begin{array}{l}\text { Moder } \\
\text { ate } \\
\text { risk }\end{array}$ \\
\hline Dijkhuizen & 2001 & Indonesia & $\begin{array}{l}\text { Mean } 4.2 \\
\text { months }\end{array}$ & 90 & 98 & $7 \mathrm{mg}$ & $24 \mathrm{w}$ & $\begin{array}{l}\text { Growth: } \\
\text { Weight- } \\
\text { Length } \\
\text { WAZ - } \\
\text { LAZ - } \\
\text { WLZ }\end{array}$ & $\begin{array}{l}\text { Poor } \\
\text { nutriti } \\
\text { onal } \\
\text { status }\end{array}$ & $\begin{array}{l}\text { Moder } \\
\text { ate } \\
\text { risk }\end{array}$ \\
\hline $\begin{array}{l}\text { Fischer } \\
\text { Walker }\end{array}$ & 2009 & $\begin{array}{l}\text { Banglade } \\
\text { sh }\end{array}$ & $\begin{array}{l}6.3 \pm 0.3 \\
\text { months }\end{array}$ & 140 & 141 & $2,8 \mathrm{mg}$ & $24 \mathrm{w}$ & $\begin{array}{l}\text { Growth: } \\
\text { Weight - }\end{array}$ & $\begin{array}{l}\text { Nutriti } \\
\text { onally }\end{array}$ & $\begin{array}{l}\text { Moder } \\
\text { ate }\end{array}$ \\
\hline
\end{tabular}


ACCEPTED MANUSCRIPT

\begin{tabular}{|c|c|c|c|c|c|c|c|c|c|c|}
\hline Gardner & 2005 & Jamaica & $\begin{array}{l}9 \text { to } 30 \\
\text { months }\end{array}$ & 59 & 55 & $10 \mathrm{mg}$ & $24 \mathrm{w}$ & $\begin{array}{l}\text { Length } \\
\text { Growth: } \\
\text { Weight - } \\
\text { Length } \\
\text { WAZ - } \\
\text { LAZ - WLZ }\end{array}$ & $\begin{array}{l}\text { at risk } \\
\text { Poor } \\
\text { nutriti } \\
\text { onal } \\
\text { status }\end{array}$ & $\begin{array}{l}\text { risk } \\
\text { Moder } \\
\text { ate } \\
\text { risk }\end{array}$ \\
\hline $\begin{array}{l}\text { Hamadani } \\
\text { (a) (b) }\end{array}$ & 2001 & $\begin{array}{l}\text { Banglade } \\
\text { sh }\end{array}$ & $\begin{array}{l}1 \text { to } 13 \\
\text { months }\end{array}$ & 109101 & $\begin{array}{l}103 \\
97\end{array}$ & $5 \mathrm{mg}$ & $28 \mathrm{w} 52 \mathrm{w}$ & $\begin{array}{l}\text { Growth: } \\
\text { WAZ - } \\
\text { LAZ WLZ }\end{array}$ & $\begin{array}{l}\text { Poor } \\
\text { nutriti } \\
\text { onal } \\
\text { status }\end{array}$ & $\begin{array}{l}\text { High } \\
\text { risk }\end{array}$ \\
\hline $\begin{array}{l}\text { Heinig (a) } \\
\text { (b) For } \\
\text { Head } \\
\text { Circunf. }\end{array}$ & 2006 & USA & $\begin{array}{l}3 \text { to } 10 \\
\text { months }\end{array}$ & 373737 & $\begin{array}{l}33 \\
33 \\
33\end{array}$ & $5 \mathrm{mg}$ & $\begin{array}{l}16 \mathrm{w} 40 \mathrm{w} \\
24 \mathrm{w}\end{array}$ & $\begin{array}{l}\text { Growth: } \\
\text { Weight - } \\
\text { Length } \\
\text { MUAC } \\
\text { Head } \\
\text { Circumferen } \\
\text { ce }\end{array}$ & $\begin{array}{l}\text { Health } \\
\mathrm{y}\end{array}$ & $\begin{array}{l}\text { Low } \\
\text { risk }\end{array}$ \\
\hline Lind & 2004 & Indonesia & $\begin{array}{l}6 \text { to } 12 \\
\text { months }\end{array}$ & 164 & 163 & $10 \mathrm{mg}$ & $8 \mathrm{w}$ & $\begin{array}{l}\text { Growth: } \\
\text { WAZ - } \\
\text { LAZ-WLZ }\end{array}$ & $\begin{array}{l}\text { Health } \\
\mathrm{y}\end{array}$ & $\begin{array}{l}\text { Low } \\
\text { risk }\end{array}$ \\
\hline $\begin{array}{l}\text { Meeks } \\
\text { Gardner }\end{array}$ & 1998 & Jamaica & $\begin{array}{l}6 \text { to } 24 \\
\text { months }\end{array}$ & 24 & 31 & $5 \mathrm{mg}$ & $12 \mathrm{w}$ & $\begin{array}{l}\text { Growth: } \\
\text { Head } \\
\text { Circumferen } \\
\text { ce }\end{array}$ & $\begin{array}{l}\text { Poor } \\
\text { nutriti } \\
\text { onal } \\
\text { status }\end{array}$ & $\begin{array}{l}\text { Moder } \\
\text { ate } \\
\text { risk }\end{array}$ \\
\hline Muller & 2003 & $\begin{array}{l}\text { Burkina } \\
\text { Faso }\end{array}$ & $\begin{array}{l}\text { Zn group: } \\
18.7 \pm 7.0 \\
\text { moPlacebo } \\
\text { group: } 17.6 \\
\pm 6.5 \text { mo }\end{array}$ & 329 & 332 & $1,78 \mathrm{mg}$ & $24 \mathrm{w}$ & $\begin{array}{l}\text { Growth: } \\
\text { MUAC }\end{array}$ & $\begin{array}{l}\text { Nutriti } \\
\text { onally } \\
\text { at risk }\end{array}$ & $\begin{array}{l}\text { Low } \\
\text { risk }\end{array}$ \\
\hline Ninh & 1996 & Vietnam & $\begin{array}{l}4 \text { to } 36 \\
\text { months }\end{array}$ & 73 & 73 & $10 \mathrm{mg}$ & $20 \mathrm{w}$ & $\begin{array}{l}\text { Growth: } \\
\text { Weight - } \\
\text { Length } \\
\text { WAZ - }\end{array}$ & $\begin{array}{l}\text { Poor } \\
\text { nutriti } \\
\text { onal } \\
\text { status }\end{array}$ & $\begin{array}{l}\text { Low } \\
\text { risk }\end{array}$ \\
\hline
\end{tabular}




\section{ACCEPTED MANUSCRIPT}

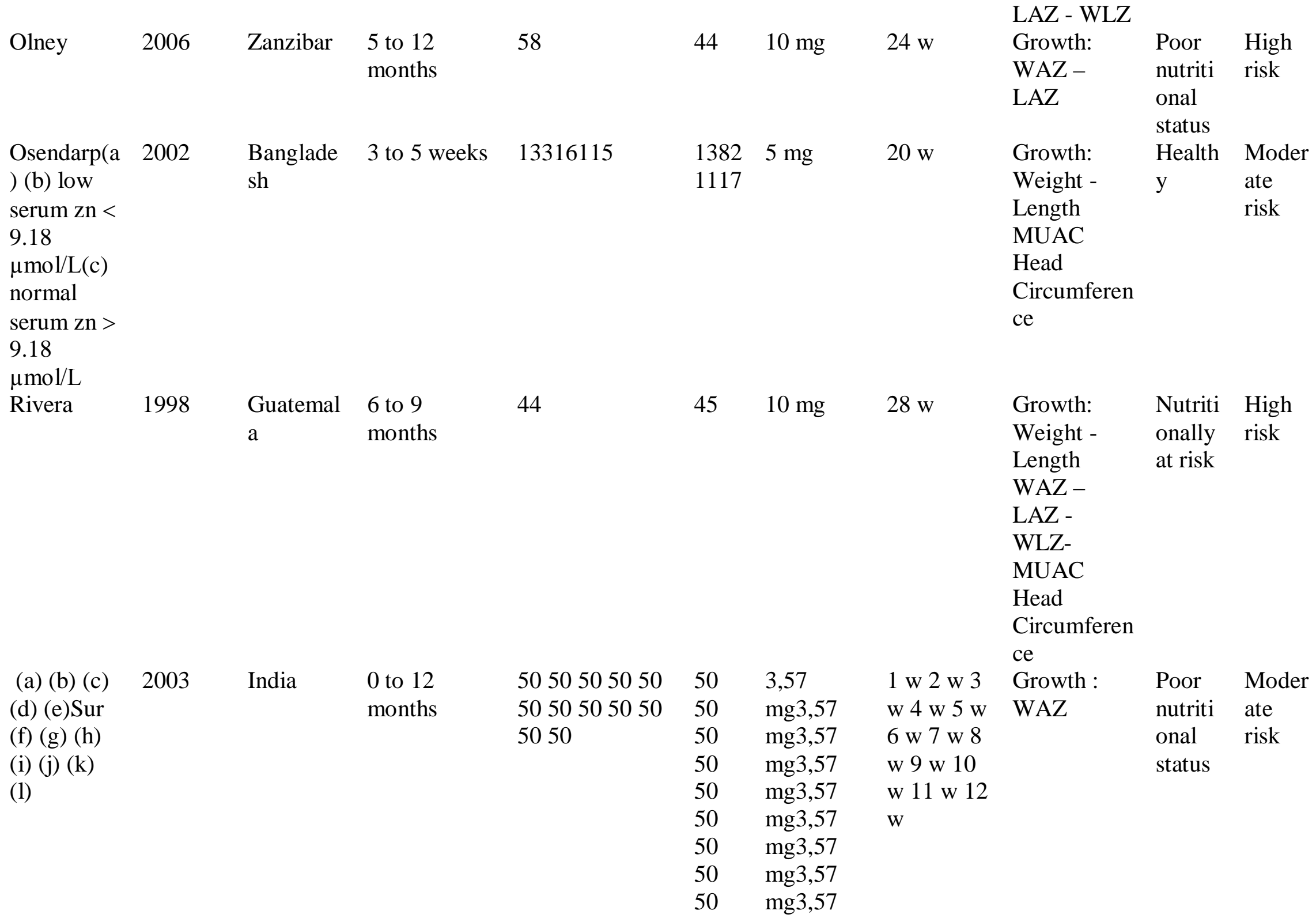




\section{ACCEPTED MANUSCRIPT}

\begin{tabular}{|c|c|c|c|c|c|c|c|c|c|c|}
\hline $\begin{array}{l}\text { (a) Umeta } \\
\text { (b) }\end{array}$ & 2000 & Ethiopia & $\begin{array}{l}\text { Zinc stunted: } \\
9.5 \pm 2.0 \text { mo } \\
\text { Placebo } \\
\text { stunted: } 9.7 \\
\pm 2.0 \text { mo } \\
\text { Zinc non } \\
\text { stunted: } 9.3 \\
\pm 2.1 \text { mo } \\
\text { Placebo non } \\
\text { stunted: } 9.2 \\
\pm 2.0 \text { mo }\end{array}$ & 4745 & $\begin{array}{l}47 \\
45\end{array}$ & $8,57 \mathrm{mg}$ & $24 \mathrm{w}$ & $\begin{array}{l}\text { Growth: } \\
\text { MUAC }\end{array}$ & $\begin{array}{l}\text { Health } \\
\text { y } \\
\text { (stunte } \\
\text { d- } \\
\text { non } \\
\text { stunte } \\
\text { d) }\end{array}$ & $\begin{array}{l}\text { High } \\
\text { risk }\end{array}$ \\
\hline $\begin{array}{l}\text { Walravens } \\
\text { Boys Girls }\end{array}$ & 1989 & USA & $\begin{array}{l}8 \text { to } 27 \\
\text { months }\end{array}$ & 1312 & $\begin{array}{l}13 \\
12\end{array}$ & $\begin{array}{l}5,7 \mathrm{mg} \\
5,7 \mathrm{mg}\end{array}$ & $24 \mathrm{w}$ & $\begin{array}{l}\text { Growth: } \\
\text { Weight - } \\
\text { Length }\end{array}$ & $\begin{array}{l}\text { Nutriti } \\
\text { onally } \\
\text { at risk }\end{array}$ & $\begin{array}{l}\text { Low } \\
\text { risk }\end{array}$ \\
\hline $\begin{array}{l}\text { Wasantwis } \\
\text { ut }\end{array}$ & 2006 & Thailand & $\begin{array}{l}4 \text { to } 6 \\
\text { months }\end{array}$ & 153 & 151 & $10 \mathrm{mg}$ & $24 \mathrm{w}$ & $\begin{array}{l}\text { Growth: } \\
\text { Weight - } \\
\text { Length } \\
\text { WAZ - } \\
\text { LAZ - WLZ }\end{array}$ & $\begin{array}{l}\text { Health } \\
\mathrm{y}\end{array}$ & $\begin{array}{l}\text { Low } \\
\text { risk }\end{array}$ \\
\hline
\end{tabular}




\section{ACCEPTED MANUSCRIPT}

Table 3: Meta-regression. Multivariate adjusted mean beta for Growth (Length) (95\% confidence interval) by different characteristics of the studies included in the meta-analysis

\begin{tabular}{|c|c|c|c|c|}
\hline & $\mathbf{n}$ & Mean beta's & $\begin{array}{c}\text { Confidence interval } \\
(95 \%)\end{array}$ & $P$ ANCOVA* \\
\hline \multicolumn{5}{|l|}{ Growth: Length } \\
\hline \multicolumn{5}{|l|}{ By time } \\
\hline 4 to 20 weeks & 5 & 0.0113 & 0.008 to 0.0219 & \\
\hline \multirow[t]{2}{*}{$>20$ weeks } & 10 & -0.0026 & -0.0089 to 0.0037 & \\
\hline & & & & 0.008 \\
\hline \multicolumn{5}{|l|}{ By Dose } \\
\hline 1 to $4 \mathrm{mg}$ & 1 & -0.0058 & -0.0245 to 0.0130 & \\
\hline 4,1 to $8 \mathrm{mg}$ & 8 & 0.0162 & 0.0078 to 0.0245 & \\
\hline 8,1 to $12 \mathrm{mg}$ & 5 & 0.0057 & -0.0016 to 0.0130 & \\
\hline \multirow[t]{2}{*}{$>12 \mathrm{mg}$} & 1 & 0.0014 & -0.0200 to 0.0229 & \\
\hline & & & & 0.023 \\
\hline \multicolumn{5}{|l|}{ By Nutritional situation } \\
\hline Healthy & 7 & 0.0010 & -0.0066 to 0.0086 & \\
\hline Nutritionally at risk & 5 & 0.0128 & 0.0025 to 0.0230 & \\
\hline \multirow[t]{2}{*}{ Poor nutritional situation } & 3 & -0.0006 & -0.0122 to 0.0110 & \\
\hline & & & & 0.083 \\
\hline \multicolumn{5}{|l|}{ By Risk of Bias } \\
\hline Low & 6 & 0.0016 & -0.0084 to 0.0116 & \\
\hline Moderate & 7 & 0.0074 & -0.0013 to 0.0161 & \\
\hline \multirow[t]{2}{*}{ High } & 2 & 0.0042 & -0.0105 to 0.0189 & \\
\hline & & & & 0.409 \\
\hline
\end{tabular}

* Adjusted for the rest of variables in the table 


\section{ACCEPTED MANUSCRIPT}

Table 4: Pooled beta (95\% confidence intervals) for Growth according to the intervention group.

Subgroup analyses.

\begin{tabular}{|c|c|c|c|}
\hline & Pooled estimates $(\beta)$ & $\mathrm{Chi}^{2}$ (d.f., P) & $\mathbf{I}^{2} *$ \\
\hline \multicolumn{4}{|l|}{ Growth: Length } \\
\hline All Studies $(\mathrm{n}=15)$ & $0.001(-0.002$ to 0.004$)$ & $25.30(14,0.03)$ & $45 \%$ \\
\hline \multicolumn{4}{|l|}{ By time } \\
\hline 4 to 20 weeks $(n=5)$ & $0.01(0$ to 0.02$)$ & $4.93(4,0.29)$ & $19 \%$ \\
\hline$>20$ weeks & $-0.001(-0.003$ to 0.002$)$ & $15.18(9,0.09)$ & $41 \%$ \\
\hline \multicolumn{4}{|l|}{ By dose } \\
\hline 1 to $4 \mathrm{mg}(\mathrm{n}=1)$ & $0(-0.01$ to 0.01$)$ & & \\
\hline 4,1 to $8 \mathrm{mg}(\mathrm{n}=8)$ & $0.003(0$ to 0.01$)$ & $7.81(7,0.35)$ & $10 \%$ \\
\hline 8,1 to $12 \mathrm{mg}(\mathrm{n}=5)$ & $0(-0.002$ to 0.004$)$ & $6.85(4,0.14)$ & $42 \%$ \\
\hline$>12 \mathrm{mg}(\mathrm{n}=1)$ & $0.01(-0.02$ to 0$)$ & & \\
\hline
\end{tabular}

* $\mathrm{I}^{2}$ Index measures the extent of the heterogeneity 


\section{ACCEPTED MANUSCRIPT}

Table 5: Pooled beta (95\% confidence intervals) for Growth according to the intervention group.

\section{Sensitivity Analyses}

\begin{tabular}{|c|c|c|c|}
\hline & Pooled estimates $(\beta)$ & $\mathrm{Chi}^{2}$ (dif, P) & $\mathbf{I}^{2}$ \\
\hline \multicolumn{4}{|l|}{ Growth: Weight } \\
\hline All studies $(n=15)$ & $0.004(-0.004$ to 0.01$)$ & $21.05(14,0.10)$ & $33 \%$ \\
\hline $\begin{array}{l}\text { All Studies excluding } \\
(\mathrm{n}=3)\end{array}$ & $0(-0.005$ to 0.01$)$ & $15.53(11,0.16)$ & $29 \%$ \\
\hline Osendrap et al. $2002 b$ & $0.12(0.01$ to 0.23$)$ & & \\
\hline Walravens et al. 1989 a & $0.03(-0.04$ to 0.10$)$ & & \\
\hline Walravens et al. $1989 \mathrm{~b}$ & $0.03(-0.04$ to 0.10$)$ & & \\
\hline \multicolumn{4}{|l|}{ Growth: MUAC } \\
\hline All studies $(n=9)$ & $0.003(-0.003$ to 0.01$)$ & $6.91(8,0.55)$ & $0 \%$ \\
\hline $\begin{array}{l}\text { All Studies excluding } \\
(\mathrm{n}=1)\end{array}$ & $0(-0.003$ to 0.01$)$ & $6.43(7,0.49)$ & $0 \%$ \\
\hline Bates et al.1993 & $-0.03(-0.12$ to 0.06$)$ & & \\
\hline \multicolumn{4}{|l|}{ Growth: WAZ } \\
\hline All studies $(n=22)$ & $0.06(0.02$ to 0.10$)$ & $31.14(21,0.07)$ & $33 \%$ \\
\hline $\begin{array}{l}\text { All Studies excluding } \\
(\mathrm{n}=9)\end{array}$ & $0.03(0$ to 0.07$)$ & $15.67(12, \quad 0.21)$ & $23 \%$ \\
\hline Sur et al. $2003 d$ & $0.11(-0.13$ to 0.34$)$ & & \\
\hline Sur et al. $2003 e$ & $0.15(-0.10$ to 0.39$)$ & & \\
\hline Sur et al. $2003 f$ & $0.05(-0.22$ to 0.33$)$ & & \\
\hline Sur et al. $2003 \mathrm{~g}$ & $0.07(-0.22$ to 0.36$)$ & & \\
\hline Sur et al. $2003 \mathrm{~h}$ & $0.19(-0.10$ to 0.48$)$ & & \\
\hline Sur et al. $2003 i$ & $0.15(-0.13$ to 0.44$)$ & & \\
\hline Sur et al. $2003 j$ & $0.15(-0.13$ to 0.44$)$ & & \\
\hline Sur et al. $2003 k$ & $0.25(-0.05$ to 0.56$)$ & & \\
\hline
\end{tabular}




\section{ACCEPTED MANUSCRIPT}

\begin{tabular}{|l|c|c|c|}
\hline Sur et al. $2003 \quad l$ & $0.55(0.24$ to 0.86$)$ & & \\
\hline Growth: Length & & & \\
\hline All studies (n=15) & $0.001(-0.002$ to 0.004$)$ & $25.30(14,0.03)$ & $45 \%$ \\
\hline $\begin{array}{l}\text { All Studies excluding } \\
\text { (n=1) }\end{array}$ & $0(-0.002$ to 0.004$)$ & $24.67(13,0.03)$ & $47 \%$ \\
\hline Osendrap et al. $2002 \quad b$ & $0.03(-0.04$ to 0.10$)$ & & \\
\hline
\end{tabular}

$1^{2}$ Index measures the extent of the heterogeneity 